\title{
In vitro and In silico Evaluation of Structurally Diverse Benzyl-pyrrolidine-3-ol Analogues as Apoptotic Agents via Caspase Activation
}

\author{
Tahira Naqvi, ${ }^{\ddagger}, 1$ Asif Amin, ${ }^{2}$ Shujat Ali, ${ }^{3}$ Mohsin Y. Lone, ${ }^{4}$ Nadeem Bashir, ${ }^{1,3}$ \\ Shafi U. Khan, ${ }^{5}$ Thet T. Htar ${ }^{5}$ and Masood Ahmad Rizvi ${ }^{\star, 3}$ \\ ${ }^{1}$ Higher Education Department, Government of J®K, India. \\ ${ }^{¥}$ Current address Government College for Women M.A Road Srinagar. \\ ${ }^{2}$ Department of Biotechnology, University of Kashmir, Je K, India \\ ${ }^{3}$ Department of Chemistry, University of Kashmir, Srinagar, Jß $\nleftarrow$, India \\ ${ }^{4}$ Department of Chemistry, Indian Institute of Technology, Gandhinagar, Gujarat, India \\ ${ }^{5}$ School of Pharmacy, Monash University Jalan Lagoon Selatan, Bandar 47500, Malaysia \\ *Corresponding author: E-mail: masoodku2@gmail.com
}

Received: 02-13-2021

\begin{abstract}
The activation of caspases is central to apoptotic process in living systems. Defects in apoptosis have been implicated with carcinogenesis. Need to develop smart agents capable of inducing apoptosis in tumor cells is obvious. With this motive, diversity oriented synthesis of 1-benzylpyrrolidin-3-ol analogues was envisaged. The multi component Ugi reaction synthesized library of electronically diverse analogues was explored for cytotoxic propensity towards a panel of human cancer cell lines at $10 \mu \mathrm{M}$. The lead compounds exhibit a selective cytotoxicity towards HL-60 cells as compared to cell lines derived from solid tumors. Besides, their milder cytotoxic effect on non-cancerous cell lines reaffirm their selective action towards cancer cells only.The lead molecules were tested for their ability to target caspase-3, as a vital protease triggering apoptosis. The lead compounds were observed to induce apoptosis in HL-60 cells around $10 \mu \mathrm{M}$ concentration. The lead compounds exhibited various non-covalent supra type interactions with caspase- 3 key residues around the active site. The binding ability of lead compounds with caspase- 3 was studied via molecular docking and molecular dynamic (MD) simulations. MD simulations indicated the stability of compound-caspase-3 complex throughout the 50 ns simulation run. The stability and bio-availability of the lead compounds under physiological conditions was assessed by their interaction with Bovine Serum Albumin (BSA) as model protein. BSA interactions of lead compounds were studied by various bio-physical methods and further substantiated with in silico MD simulations.
\end{abstract}

Keywords: Benzyl-pyrrolidine-3-ol; caspase-3; molecular dynamic simulations; bioavailability, UGI reaction; Biophysical methods.

\section{Introduction}

Apoptosis or programmed cell death is a unique homeostatic process which eliminates the virus infected cells, cells with damaged DNA and cancerous cells. ${ }^{1}$ While as a series of genetic changes transform normal cell into malignant ones, evasion or resistance to apoptosis is considered as an essential factor in this malignant transformation. ${ }^{2}$ Apoptosis is a securely regulated process mediated by the family of proteases known as caspases, which cause the proteolytic cleavage of key cellular proteins inducing morphological and biochemical changes associated with apoptosis. ${ }^{3}$ Since caspases are considered as pivotal cell death effector molecules, most signaling pathways activated by anticancer drugs ultimately result in activation of caspases. Therefore caspases represent attractive targets for the development of apoptotic agents that can selectively guide the cancer cell towards apoptosis and induce their con- 
trolled cell death. Towards this endeavor of potentiating chemotherapeutics, we employed both in vitro and bioinformatics based approach to facilitate the development of putative proapoptotic agents from Benzylpyrrolidin-3-ol derivatives. A structure activity relationship (SAR) based drug designing strategy relying on the structural diversity and ability to interact with a defined bio-target was investigated. A library of structurally diverse, 1-benzylpyrrolidin-3-ol analogues was synthesized by multi component Ugi reaction ${ }^{4,5}$ and assessed for its ability to induce apoptosis in a panel of human cancer cell lines. Benzylpyrrolidin-3-ol, is a privileged structural motif present in wide range of naturally occurring bioactive compounds and a common intermediate in synthesis of many pharmacoactive molecules. ${ }^{6}$ Pharmaceuticals such as anti-hypertensive barnidipine, ${ }^{7}$ quinolinone antibiotic clinafloxacin $\mathrm{B},{ }^{8}$ muscarinic receptor antagonists darifenacine $C,{ }^{8}$ carbapenem antibiotic RS-533, ${ }^{9}$ anticoagulant DX- $9065 \mathrm{a}^{10}$ and naturally occurring detoxification agent detoxin $\mathrm{A} 1-\mathrm{D}^{11}$ have 3 -substituted pyrrolidine moiety in the pharmacophoric unit Scheme 1. displayed a range of cytotoxicity towards studied panel of cancer cell lines: HL-60 (human leukemia), A549 (human lung adenocarcinoma), NCI H322 (human brochioalveolar carcinoma), A431 (human epidermoid carcinoma), and T98G (human Glioblastoma), with $\mathbf{5 j}$ and $\mathbf{5 p}$ observed as lead cytotoxic compounds. The lead compounds $\mathbf{5 j}$ and 5p exhibit a selective cytotoxicity towards HL-60, cells as compared to cell lines derived from solid tumors. Besides, their milder cytotoxic effect on non-cancerous cell lines reaffirm their selective action towards cancer cells only. Computational methods are very unique for mechanistic investigation and prediction, ${ }^{25-28}$ as such Molecular docking was employed to explore possible modes of the interaction along with prominent supra interactions between the lead compounds and caspase- 3 target. To investigate the binding stability of lead compounds with caspase-3, $50 \mathrm{~ns}$ molecular dynamic (MD) simulation was also carried out. From the pharmaceutical perspectives of bioavailability, and drug stability, the interaction of lead compounds $\mathbf{5 j}$ and $\mathbf{5 p}$ was explored with the Bovine serum albumin (BSA) as modular transport protein. The interaction of $\mathbf{5 j}$<smiles>CC(=O)C1=C(C)NC(C)=C(C(=O)O[C@H]2CC3CCC2CC3)C1c1cccc([N+](=O)[O-])c1</smiles>

Barnidipine

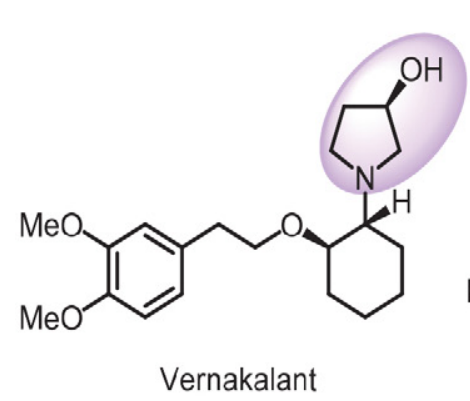

Vernakalant

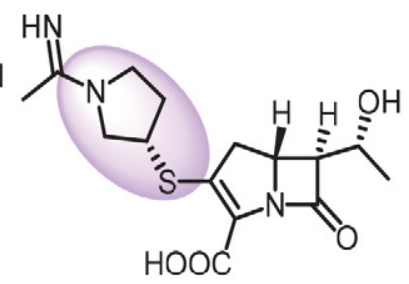

RS-533
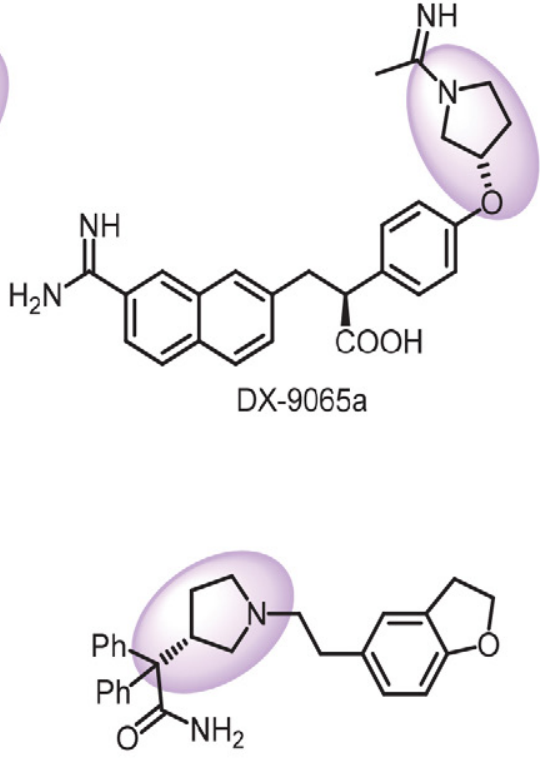

Darifenacine-C

Scheme 1. Bioactive molecules containing 3-substituted pyrrolidine moiety.

Thus, keeping in view importance of 1-benzylpyrrolidin-3-ol moiety in medicinal chemistry and in continuation of our research interests in designing synthetic methodologies and chemical biology, ${ }^{12-24}$ we envisaged diversity-oriented synthesis of 1-benzylpyrrolidin-3-ol analogues via Ugi multi component reaction (Ugi-4CR). As an initial screening step, the synthesized library of the compounds (5a-p) was screened for ability to induce cytotoxicity towards a panel of human cancer cell lines. In the synthesized library, compounds at $10 \mu \mathrm{M}$ concentration and $\mathbf{5 p}$ with BSA was quantified by in vitro biophysical methods and was further explored using molecular dynamic (MD) simulations.

\section{Experimental}

\section{1. Materials and Methods}

In an initial attempt, equimolar amounts of substrates were used under standard U-4CR conditions in 
methanol at room temperature, but no product formation took place. However, when attempted at higher temperatures $\left(80{ }^{\circ} \mathrm{C}\right)$, reaction afforded the Ugi product (5a) in $90 \%$ yield.

General procedure for Ugi-4 component reaction (5ap): 1-(2-aminobenzyl)pyrrolidin-3-ol-(2-aminobenzyl) pyrrolidin-3-ol (0.096 g, $0.5 \mathrm{mmol})$, p-nitro benzaldehyde $(0.0755 \mathrm{~g}, 0.5 \mathrm{mmol})$, benzoic acid $(0.061 \mathrm{gm}, 0.5 \mathrm{mmol})$ and tert-butyl isocyanide $(169 \mu \mathrm{L}, 1.5 \mathrm{mmol})$ were dissolved in $\mathrm{MeOH}(5 \mathrm{~mL})$ and refluxed at $80{ }^{\circ} \mathrm{C}$. Reaction mixture was refluxed until 1-(2-aminobenzyl) pyrrolidin-3-ol completely disappeared on TLC. This followed concentrating reaction mixture over vacum evaporator. Ethylacetate was added to reaction system and extracted with saturated aqueous $\mathrm{NaHCO}_{3}$ followed by brine solution. The organic layer was dried with $\mathrm{Na}_{2} \mathrm{SO}_{4}$ and residue was purified by column chromatography $\left(\mathrm{CH}_{3} \mathrm{OH}: \mathrm{CH}_{2} \mathrm{Cl}_{2}\right.$ $1: 20$ ) to give compound $\mathbf{5 a}$ in $78 \%$ yield. Characterization was done by ${ }^{1} \mathrm{H}$ NMR and High-resolution electrospray ionisation mass spectrometry by comparing to accurate mass measurements and molecular formula.

\section{Cell culture}

Cell lines including HL-60 (human leukemia), A549 (human lung adenocarcinoma), NCI H322 (human brochioalveolar carcinoma), A431 (human epidermoid carcinoma), and T98G (human Glioblastoma) used in the study were obtained from National Centre for Cell Science (NCCS), Pune, India. Proper authentication of each cell line was carried out using standard procedures at the repository. HL-60 was maintained in RPMI-1640 while as the rest of cell lines were cultured using DMEM supplemented with $10 \%$ fetal bovine serum and $100 \mathrm{U} / \mathrm{ml}$ penicillin and $100 \mathrm{mg} / \mathrm{ml}$ streptomycin. Cells were cultured under standard culture conditions of $5 \% \mathrm{CO}_{2}$ and $37^{\circ} \mathrm{C}$ temperature.

\section{Cell proliferation assay}

The in vitro cytotoxicity of the synthesized compounds against chosen human cancer cell lines was determined by using SRB (sulphorhodamine B) assay. Cells were seeded at a density of $8 \times 10^{3}$ to $15 \times 10^{3}$ cells per $100 \mu \mathrm{L}$ in a well of 96 well tissue culture plates and incubated at $37{ }^{\circ} \mathrm{C}$ under $5 \% \mathrm{CO}_{2}$ and $95 \%$ relative humidity for 24 h.The test compounds(5a-5p) $(100 \mu \mathrm{L}$ in each well) were added at different concentrations and again incubated for $48 \mathrm{~h}$ in $\mathrm{CO}_{2}$ incubator. Cells were fixed with $50 \% \mathrm{w} / \mathrm{v}$ trichloroacetic acid by gently layering on the top of the wells. Subsequently, plates were incubated for $1 \mathrm{~h}$ at $4{ }^{\circ} \mathrm{C}$. Thereafter, the plates were washed with distilled water three times and air dried. Cell growth was measured by adding SRB dye $(0.4 \% \mathrm{w} / \mathrm{v}$ in $1 \%$ acetic acid, $100 \mu \mathrm{L} /$ well). The unbound dye was washed with $1 \%$ acetic acid 3 times and air dried. The dye was dissolved in tris-buffer $(100 \mu \mathrm{L} /$ well, $0.01 \mathrm{M}, \mathrm{pH} 10.4$ ) and plates were kept on mechanical shaker for $10 \mathrm{~min}$. The optical density (OD) was recorded at $540 \mathrm{~nm}$ with microplate reader (BioTek Synergy HT) . $\mathrm{IC}_{50}$ was determined by using Prism, version 5.04, from Graph Pad Software (La Jolla, CA). The assay was repeated three independent times

\section{In vitro Proliferation Assay}

HL-60 cells were seeded in 96 well microtiter plates at a density of $15 \times 10^{3}$ cells/well and treated with varying concentration of the test compounds $(5 \mathbf{a}-5 \mathbf{p})$ for $48 \mathrm{~h} .20$ $\mu \mathrm{L}$ of $2.5 \mathrm{mg} \mathrm{L}^{-1}$ of MTT dye was added to each well and incubated for $4 \mathrm{~h}$ before termination. Excess media was then blotted off and MTT purple formazan crystals were dissolved in $150 \mu \mathrm{L}$ of DMSO. Optical density was measured at $570 \mathrm{~nm}$ with microplate reader (BioTek Synergy HT). $\mathrm{IC}_{50}$ was determined by using Prism, version 5.04, from GraphPad Software (La Jolla, CA). The assay was repeated three independent times

\section{Fluorescence microscopy}

HL-60 cells were stained with DNA specific fluorescent nuclear dye 4'-6-diamidino-2-phenylindole (DAPI) to determine the nuclear morphological changes and analyzed under fluorescent microscope. Cells were treated with varying concentrations $(5,10,15 \mu \mathrm{M})$ of $5 \mathbf{j}$ and $\mathbf{5 p}$. After $24 \mathrm{~h}$ incubation, cells were washed and resuspended in PBS. Smears of cells were made on glass slides, air dried, fixed in methanol for $20 \mathrm{~min}$ at $-20^{\circ} \mathrm{C}$, again air dried and stained in dark for $20 \mathrm{~min}$ with DAPI $\left(1 \mu \mathrm{g} \mathrm{mL} \mathrm{m}^{-1}\right)$, then mounted using glycerol-PBS mixture (90:10) and analyzed under fluorescence microscope (Olympus) using UV filter at $40 \mathrm{Xmagnification.} \mathrm{The} \mathrm{experiment} \mathrm{was} \mathrm{repeated} \mathrm{three}$ independent times.

\section{Cell cycle analysis}

For cell cycle phase distribution analysis, HL-60 cells $\left(5 \times 10^{5}\right)$ were seeded in a 6 well tissue culture plate and there after the cells were treated with different concentrations $(5,10,15 \mu \mathrm{M})$ of $\mathbf{5 j}$ and $\mathbf{5 p}$ compounds for $24 \mathrm{~h}$, washed with PBS and fixed in ice cold $70 \%$ ethanol at -20 ${ }^{\circ} \mathrm{C}$, overnight. Cells were then centrifuged and washed with PBS followed by the addition of RNase $(100 \mu \mathrm{g} / \mathrm{mL})$ at $37^{\circ} \mathrm{C}$ for $45 \mathrm{~min}$ and stained with propidium iodide (PI) to determine the cell cycle phase distribution. DNA fluorescence was measured using flow cytometer FACS Aria (Becton Dickinson, USA) and resulting DNA distributions were analyzed for the proportions of cells in apoptosis, G1phase, S- phase, and G2-M phases of the cell cycle.

\section{Mitochondrial membrane potential}

Mitochondrial membrane potential was measured using Rhodamine-123\{RH-123\} staining and analyzed by flow cytometer. HL- 60 cells $\left(5 \times 10^{5}\right)$ were treated with different concentrations $(5,10,15 \mu \mathrm{M})$ of $\mathbf{5 j}$ and $\mathbf{5 p}$ for $24 \mathrm{~h}$. Before termination of experiment, cells were treated with RH-123 (200nM) for $1 \mathrm{hr}$, centrifuged and washed with 
PBS. Cells were re suspended in PBS and fluorescence intensity was analyzed by BD-FACS Aria flow cytometer with an excitation wavelength of $488 \mathrm{~nm}$ and emission wavelength of $525 \mathrm{~nm}$ in FITC channel. The experiment was repeated three independent times.

\section{Preparation of protein lysates, estimation and western blot analysis}

After treatment with different concentrations $(5,10,15 \mu \mathrm{M})$ of $\mathbf{5 j}$ and $\mathbf{5 p}$, HL- 60 cells $\left(3 \times 10^{6}\right)$ were harvested, washed with PBS and resuspended in lysis buffer containing RIPA and protease and phosphatase inhibitor cocktail. Cells were incubated for $45 \mathrm{~min}$ on ice with periodic vortexing and centrifuged at $14000 \mathrm{x} \mathrm{g}$ for $15 \mathrm{~min}$. Supernatant was collected and stored at $-20^{\circ} \mathrm{C}$. The protein concentration was determined with Quanti Pro BCA assay kit according to manufacturer's protocol using Bovine Serum Albumin (BSA) as standard. An equal concentration of protein was subjected to $10 \%$ SDS-PAGE and transferred to polyvinylidene difluoride membrane at $4{ }^{\circ} \mathrm{C}$. The membrane was blocked with $3 \%$ BSA inTBS-Tween 20 and probed with primary PARP-1 (1:3000), Abcam, rabbit polyclonal, $\beta$-actin (1:5000), Sigma Aldrich, rabbit polyclonal and horseradish peroxidase linked respective secondary antibodies (1:5000), Thermo Scientific Ltd.The signals were detected by using western chemiluminescent HRP substrate and exposed to X-ray film for analysis.

\section{BSA binding experiments of $5 j$ and $5 p$}

Spectrophotometric measurements were carried on Shimadzu 1650 UV-visible spectrophotometer with thermostatic control. Fluorescence spectra were recorded using $1.0 \mathrm{~cm}$ quartz cells over Shimadzu 184 Spectrofluorimeter -5000(Japan) equipped with a xenon flash lamp and a thermostat bath. The absorption measurements of fixed BSA concentration $(50 \mu \mathrm{M})$ was recorded in the range of 200-350 $\mathrm{nm}$ in presence of increasing concentration of lead compounds $5 \mathbf{j}$ and $\mathbf{5 p}(10-50 \mu \mathrm{L}$ of $1 \mathrm{mM})$. In fluorescence quenching experiments, BSA concentration was fixed at $50 \mu \mathrm{M}$ to which $10-50 \mu \mathrm{L}$ of $1 \mathrm{mMconcentration} \mathrm{of}$ $5 \mathbf{j}$ and $\mathbf{5 p}$ was added. Fluorescence spectra were recorded at three different temperatures $(298,303$ and $308 \mathrm{~K})$ in TrisHCl buffer solution $(\mathrm{pH}=7.4)$ in the range of $300-500$ $\mathrm{nm}$ upon excitation at wavelength of $\lambda 296 \mathrm{~nm}$ in each case.

\section{In Silico studies: \\ Molecular docking}

The lead molecules $\mathbf{5 j}$ and $\mathbf{5 p}$ were docked into the condensation site of Caspase-3 (PDB ID:3DEI) by using CDOCKER utilities within the Discovery Studio Client 18.1.0. Initially, a receptor description file was prepared and the binding cavity was defined around the co-crystallized ligand isoquinoline-1,3,4-trione derivative (RXB). Re-docking of the RXB was furnished to validate the appli- cability of the docking protocol. Among the generated receptor-ligand conformations of $\mathbf{5 j}$ and $\mathbf{5 p}$, the one with lowest CDOCKER energies were analysed for the interactions accountable for biological activity.

\section{Molecular dynamics (MD) simulations}

MD simulations were performed to study the stability of lead compounds $\mathbf{5 j}$ and $\mathbf{5 p}$ in complex with the caspase-3 (PDB ID:3DEI) and BSA (PDB ID:4OR0) proteins. As the caspase- 3 is active in dimer form (A and $\mathrm{C}$ chain), therefore, both the chains along with lead compounds were chosen for simulation whereas, due to identical nature of both the chains of BSA, only chain-A complexed with $\mathbf{5} \mathbf{j}$ and $\mathbf{5 p}$ was considered for the simulation overall a set of four-ligand complexes viz $5 \mathbf{j}$-caspase-3, 5p-caspase-3, 5jBSA and 5p-BSA were simulated for the duration of 50ns. (For more details see supporting information)

\section{Results and Discussion}

\section{1. Synthesis of Benzyl-pyrrolidine-3-ol Analogues}

Diversity targeted synthesis of sixteen (5a-p) 1-benzyl-pyrrolidine-3-ol derivatives was attempted using Ugi four component reaction (Figure S1). In diversity oriented synthesis, the primary amine functionality of 1-(2-aminobenzyl) pyrrolidin-3-ol (1) and tert-butyl isocyanide (4) were fixed components while as different aldehydes and acid molecules were varying components of Ugi reaction for synthesized analogs. For reaction optimization, 1-(2-Aminobenzyl) pyrrolidin-3-ol (1), p-nitro benzaldehyde (2a), benzoic acid (3) and tert-butyl isocyanide were selected as model substrates. After optimizing Ugi reaction conditions with model substrates. The optimized reaction was then subjected to different aromatic aldehydes and acid molecules as substrates. The diversity oriented synthesis was attempted using a set of aromatic aldehydes to give the corresponding products in good yields. Furthermore, the optimized protocol was used for synthesis of a follow-up library with 1-(2-aminobenzyl) pyrrolidin-3-ol (1), p-trifluromethoxy benzaldehyde (2b) and tert-butyl isocyanide (4), and a set of aromatic and aliphatic acids as substrates resulting in good yields of corresponding Ugi adducts. In addition, the reaction conditions were observed to be well tolerable to amino acids and mono protected diacids. From substrate scope investigation, reaction behavior was observed to be largely insensitive (except for reaction times and \% yields) to electronic and steric differences in substrate variants to produce corresponding products (5ap) in good yields (Figure 1). The reagents used in the synthesis are color coded in Figure 1 and their chemical structures are summarized in Table S1 (see supporting information) 


\section{2. Lead molecules from Benzyl-pyrrolidine- 3-ol Analogues Exhibit Favorable Interactions with Caspase-3}

Prior to in silico studies, all the compounds(5a-p) in the synthesized library were screened for their ability to induce cytotoxicity against a panel of human cancer cell lines including HL-60 (human leukemia), A549 (human lung adenocarcinoma), NCI H322 (human brochioalveolar carcinoma), A431 (human epidermoid carcinoma), and T98G (human Glioblastoma). It was observed that the compounds $\mathbf{5 j}$ and $\mathbf{5 p}$ induce significant inhibition of cell growth in selected human cancer cell lines Figure 2. (Table S2 and Figure S2) The lead compounds $\mathbf{5 j}$ and $\mathbf{5 p}$ exhibit a selective cytotoxicity towards HL-60, cells as compared to cell lines derived from solid tumors $\left(\mathrm{IC}_{50}\right.$ values of the

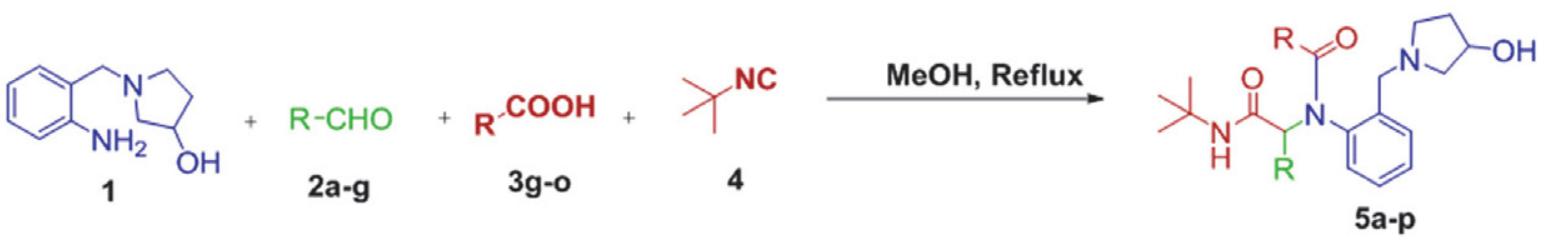<smiles></smiles><smiles></smiles><smiles>CC(C)(C)NC(=O)C(c1ccc(C(C)(C)C)c(Br)c1)N(C(=O)c1ccccc1)c1ccccc1CN1CCC(O)C1</smiles><smiles>CC(C)(C)NC(=O)C(c1cc(C(F)(F)F)cc(C(F)(F)F)c1)N(C(=O)c1ccccc1)c1ccccc1CN1CCC(O)C1</smiles><smiles>CC(C)(C)NC(=O)C(c1ccc2ccccc2n1)N(C(=O)c1ccccc1)c1ccccc1CN1CCC(O)C1</smiles><smiles>CC(C)(C)NC(=O)C(c1ccccn1)N(C(=O)c1ccccc1)c1ccccc1CN1CCC(O)C1</smiles><smiles>CC(C)(C)NC(=O)C(c1cccs1)N(C(=O)c1ccccc1)c1ccccc1CN1CCC(O)C1</smiles>

$5 g(58 \%)$<smiles>CC(C)(C)NC(=O)C(c1ccc(OC(C)(C)C)cc1)N(C(=O)c1ccccn1)c1ccccc1CN1CCC(O)C1</smiles><smiles>COc1ccc(C(C(=O)NC(C)(C)C)N(C(=O)c2cccnc2Br)c2ccccc2CN2CCC(O)C2)cc1</smiles><smiles>CC(C)(C)NC(=O)C(c1ccc(OC(F)(F)F)cc1)N(C(=O)c1c(Cl)cccc1Cl)c1ccccc1CN1CCC(O)C1</smiles>

5j $(62 \%)$<smiles>CC(C)(C)NC(=O)C(c1ccc(OC(C)(C)C)cc1)N(C(=O)c1ccc(F)cc1)c1ccccc1CN1CCC(O)C1</smiles><smiles>COc1ccc(C(C(=O)NC(C)(C)C)N(C(=O)c2cccnc2)c2ccccc2CN2CCC(O)C2)cc1</smiles><smiles>C[C@H](C(=O)NC(C)(C)C)N(C(=O)[NH2+]C(C)(C)C)C(c1ccc(OC(F)(F)F)cc1)c1ccccc1CN1CCC(O)C1</smiles>

$5 \mathrm{~m}(68 \%)$<smiles>COC(=O)C(=O)N(C(=O)C(=O)NC(C)(C)C)c1ccccc1CN1CCC(O)C1</smiles>

5n $(55 \%)$<smiles>COC(=O)COC(=O)N(c1ccccc1CN1CCC(O)C1)C(C(=O)NC(C)(C)C)c1ccc(OC(F)(F)F)cc1</smiles>

$50(52 \%)$

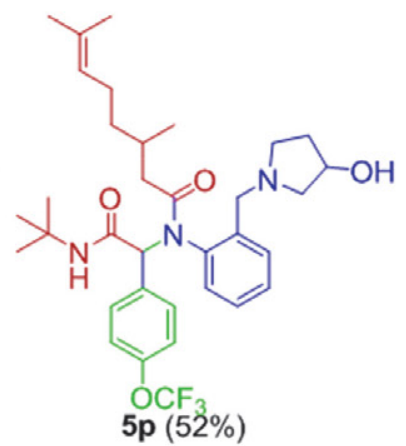

Figure 1. Diversity oriented synthesis of 1-benzyl-pyrrolidine-3-ol analogues using UGI reaction protocol. 

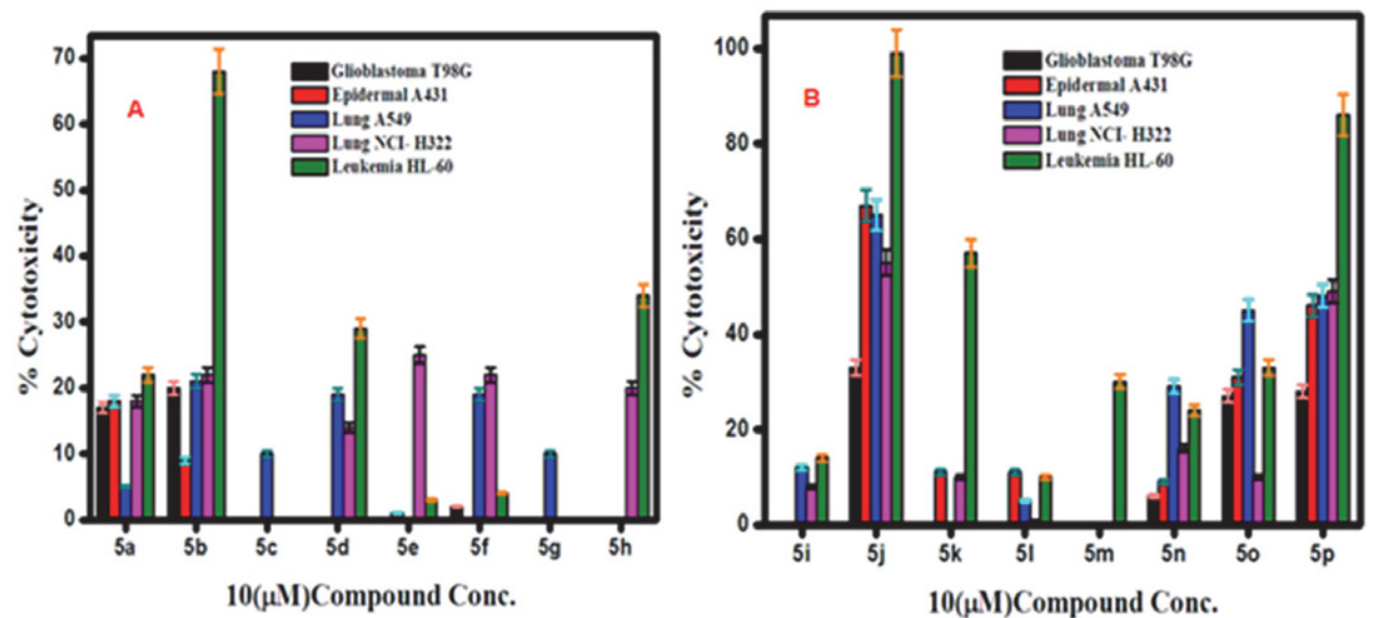

Figure 2. \% Cytotoxicity of 1-benzyl-pyrrolidine-3-ol analogues towards a panel of human cancer cells with lead compounds $\mathbf{5 j}$ and $\mathbf{5 p}$.
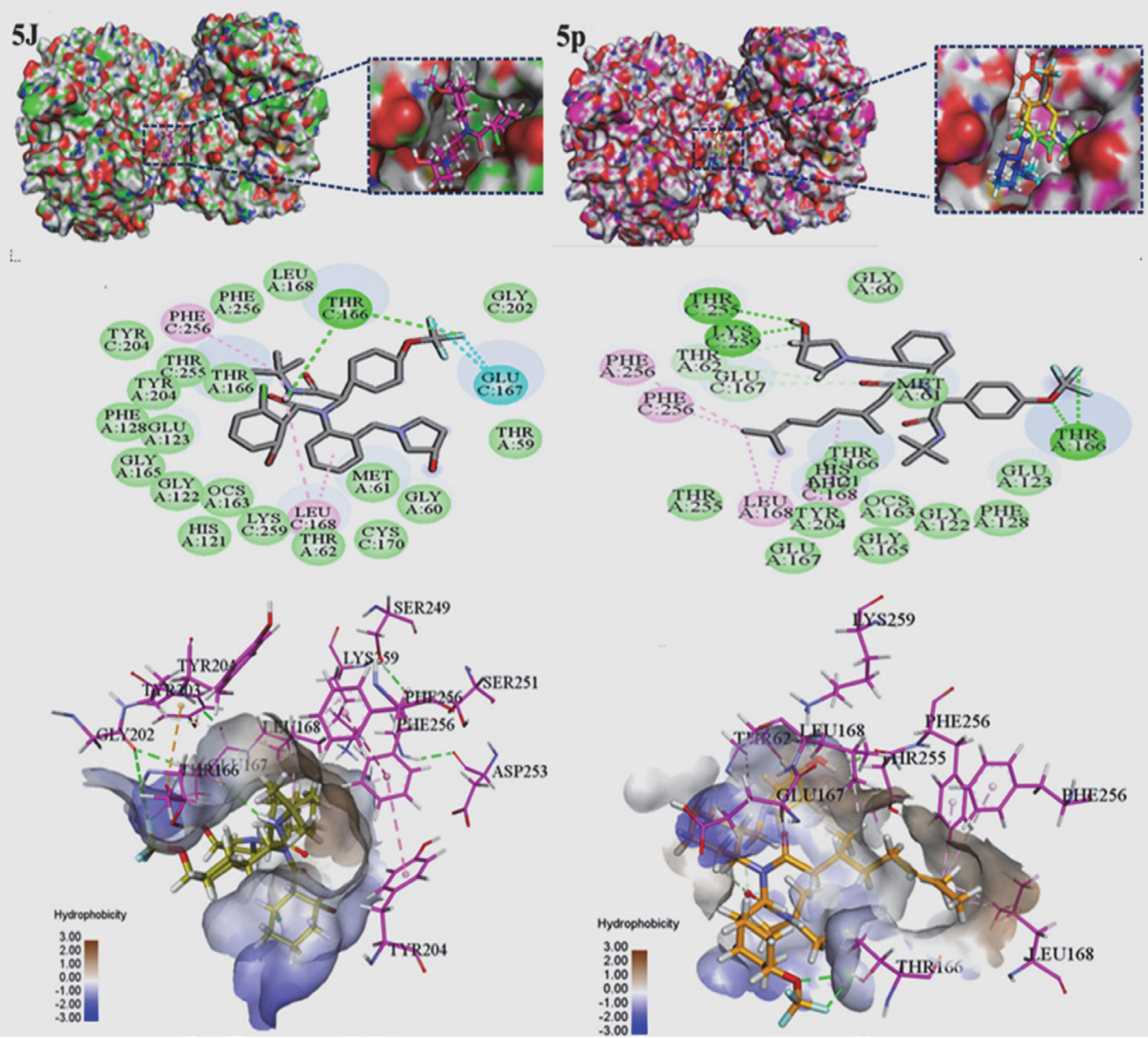

Figure 3: Surface, 2D and 3D representations of the lead molecules $5 \mathbf{j}$ and $\mathbf{5 p}$ around the active site of caspase-3. 
compounds $\mathbf{5 j}$ and $\mathbf{5 p}$ towards selected cancer cell lines Table S3). Besides, their milder cytotoxic effects on non-cancerous cell lines reaffirm their selective action towards cancer cells. Thus lead compounds were subjected to detailed investigations as apoptotic agents via in vitro and in silico studies.

Caspases are crucial mediators of cell death pathway activated by apoptosis-inducing stimuli. Among them, caspase- 3 is a frequently activated apoptotic protease, catalyzing specific cleavage of many key cellular proteins thereby it is a putative target for cytotoxic drug designing. ${ }^{29-33}$ To explore the possible modes of interaction between lead molecules and caspase- 3 , in silico studies were attempted. The detailed molecular docking and dynamic simulation studies were attempted on these lead compounds after validating the protocol by re-docking of the co-crystal ligand RXB into the active site of the caspase-3 protein. A good agreement of RMSD (less than $2 \AA$ ) between the re-docked and bound conformation of RXB affirms the usefulness of optimized protocol for subsequent studies. Thus, $\mathbf{5} \mathbf{j}$ and $\mathbf{5} \mathbf{p}$ were docked into the active site of the reference crystal structure 3DEI. From the generated docked poses, most stable pose (lowest CDOCKER interaction energies) from each compound was selected to analyze the binding interaction with the target protein.

It is evident from the $2 \mathrm{D}$ interaction plots (Figure 3 ) that amino acids from chain $\mathrm{A}$ and chain $\mathrm{C}$ were involved in forming various supra interactions with compounds $\mathbf{5} \mathbf{j}$ and $5 p$. Analysis of binding interaction between target protein and compound $\mathbf{5 j}$ and $\mathbf{5 p}$ revealed that H-bond formed with amino acid residue THR166 was common for both compounds. While in case of $\mathbf{5 j}$ amino acid residue of Glu167 was involved in forming two carbon-halogen bonds with compound. Additionally compound $5 \mathbf{p}$ was forming H-bonds with amino acid residue of Thr255 and Lys259 as shown in Figure 3B. Moreover hydrophobic interactions were also formed by His121(A), Met 61(A), Phe128(A) and Glu167(C) with compound 5j while in case of compound $\mathbf{5 p}$, hydrophobic interaction were formed by Leu168(A), Phe256(C), Phe256(A) and Leu168(C) (Figure 3C). In addition to H-bond and hydrophobic bond, in case of compound $\mathbf{5 p}$, three carbon hydrogen bonds were also formed by amino acid residue of Thr162 (A) and Glu167 (C).

To explore the binding stability of lead compounds $5 \mathbf{j}$ and $\mathbf{5 p}$ with caspase- $3,50 \mathrm{~ns}$ molecular dynamic simulations were performed. Various parameters viz. protein RMSD and RMSF, ligand RMSD and RMSF and the number of contacts established during the simulation were computed. The large-scale movements of $5 \mathbf{j}$ and $5 \mathbf{p}$ caspase- 3 complexes were found to be similar with an average fluctuation near to $3.0 \AA$ (Figure $4 \mathrm{~A}$ ). These results connote that binding of $5 \mathbf{j}$ and $5 \mathbf{p}$ at the active site have not perturbed the stability of protein backbone during the simulation. In addition, the structural integrity of protein chains and residual mobility of the ligands $(\mathbf{5 j}$ and $\mathbf{5 p}$ ) were characterized by calculating protein-RMSF. A similar kind of fluctuation pattern was noticed for both the ligands and is depicted in Figure 4B. Owing to the inherent flexibility of loops and terminals, the residues in the window of 100-200 and 350-400 residue indexes, have shown the protein-RMSF up to $4.2 \AA$. However, the protein-RMSF for most of the residues stays below $1.8 \AA$. These fewer fluctuations can be attributed to the secondary structure elements viz. alpha helices and beta strands and were observed throughout the simulation run. To check the stability of $\mathbf{5 j}$ and $\mathbf{5 p}$ within the binding pocket, ligand-RMSD and ligand-RMSF were computed (Figure 4B). It is clear from the ligand RMSD plots that the compounds $5 \mathbf{j}$ and $\mathbf{5 p}$ have shown an average deviation within the window size of 1.0-1.5 $\AA$ and $0.8-1.6 \AA$ respectively. These insignificant deviations observed throughout the simulation run affirm their stability within the binding pocket. Moreover, the atomic fluctuation of the ligand atoms were depicted from ligand-RMSF plots (Figure 4B). The ligand atoms pertaining to the polar groups displayed high fluctuations compared to the atoms concealed deep into the pocket. Besides RMSD and RMSF of the protein and ligand, the genesis of protein -ligand contacts plays an essential role in the complex binding. As can be seen from Figure 4C, that an average of $4-10$ contacts were noticed for both $5 \mathbf{j}$ and $5 \mathbf{p}$ within the protein during the simulation run of $50 \mathrm{~ns}$. Overall, an acceptable range of all the essential parameters were observed for the both $\mathbf{5 j}$ and $\mathbf{5 p}$ caspase- 3 complexes, which confirms their stability within the active site. Binding of $5 \mathbf{j}$ and $\mathbf{5} \mathbf{p}$ to the active site of caspase- 3 might alters its conformation and activate the dynamically important regions in the active site that promote its activity which gets manifested as the heightened apoptosis when HL-60 cells are treated with such compounds. Furthermore binding of these compounds to the active site of caspase-3 might enhance its activity through the sequestration of inhibitory zinc ions in a way reminiscent of small molecule mediated activation of procaspases. ${ }^{34,35}$ Thus caspase-3 binding ability of $\mathbf{5 j}$ and $\mathbf{5 p}$ predicts their propensity as apoptotic agents for controlled cancer cell death.

\section{3. Lead molecules from Benzyl-pyrrolidine- 3-ol Analogues Induce Apoptosis In vitro}

Prompted by the in silico inputs of $5 \mathbf{j}$ and $5 \mathbf{p}$ binding to caspase-3, we investigated whether these induce apoptosis under in vitro conditions. For experimental studies, HL-60 cell line was selected as being the most impacted cell line for cytotoxicity by $\mathbf{5 j}$ and $\mathbf{5 p}$. The effect of lead compounds $\mathbf{5} \mathbf{j}$ and $\mathbf{5 p}$ on caspase- 3 activity was initially evaluated using enzyme kinetics assay. The fluorimetric assay involves hydrolysis of acetyl-Asp-Glu-Val-Asp-7amido-4-methylcoumarin (Ac-DEVD-AMC) substrate by caspase-3, producing 7-amino-4-methylcoumarin (AMC) as fluorescent moiety. HL-60 cells were seeded in 96-well plate at $1 \times 10^{5}$ cells/well, and treated with $5 \mathbf{j}$ and $5 \mathbf{p}(10$ 

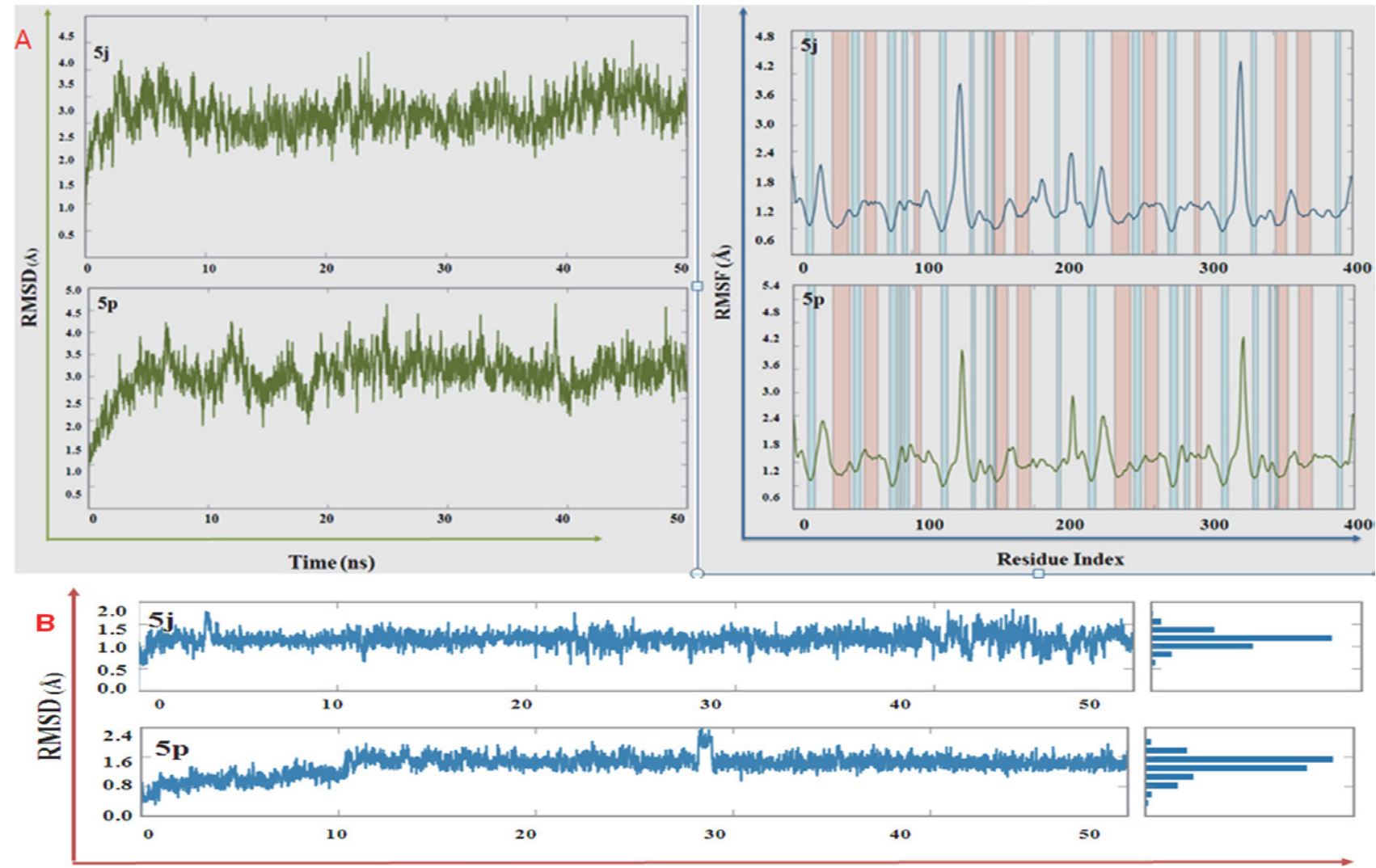

Time (ns)
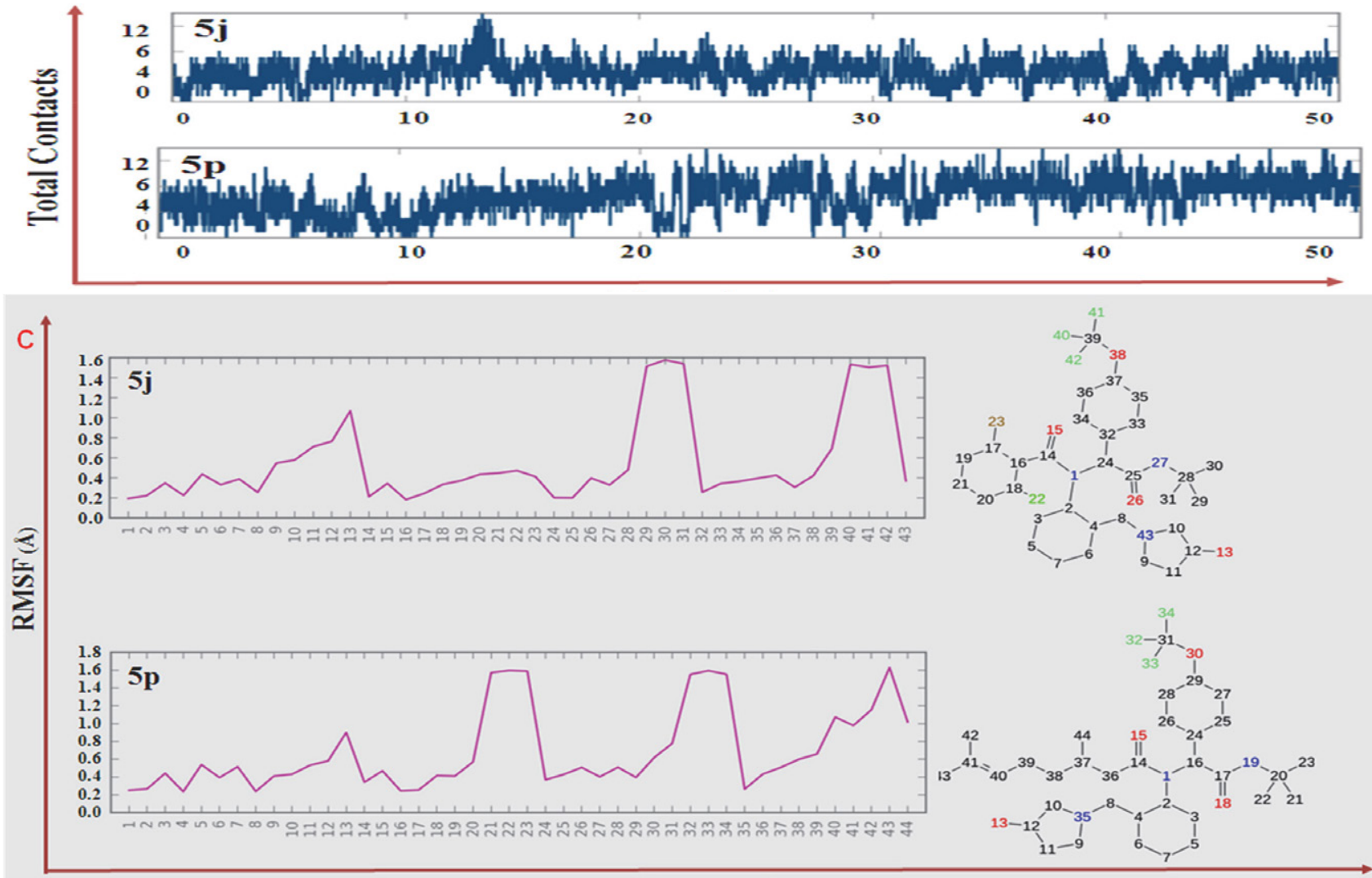

\section{Atom numbers}

Figure 4: Graphical representation of the (A) Protein (B) Ligand-RMSD and RMSF plots with respect to time and total number of contacts formed between $5 \mathrm{j}, 5 \mathrm{p}$ and the protein respectively, and $(\mathrm{C})$ with respect of atom numbers during the simulation run of $50 \mathrm{~ns}$. 
$\mu \mathrm{M})$ for $48 \mathrm{~h}$. Then, cells were lysed in lysis buffer (1X). Cell lysate were microcentrifuge for $10 \mathrm{~min}$ at $4{ }^{\circ} \mathrm{C}$. After centrifugation, supernatant was transferred to the tube and diluted. Finally, $200 \mu \mathrm{L}$ of substrate solution and $25 \mu \mathrm{L}$ of lysate solution was added to assay plates and plates were incubated at $37{ }^{\circ} \mathrm{C}$ in the dark. Relative fluorescent units (RFUs) were acquired at time intervals of $0,1,2,4$ and $6 \mathrm{hr}$ duration. During the assay, activated caspase- 3 and 7 induced by $\mathbf{5 j}$ and $\mathbf{5 p}$ cleaved the fluorogenic substrate between DEVD and AMC, resulted in highly fluorescent AMC measured at excitation of $380 \mathrm{~nm}$ and emission between $420-460 \mathrm{~nm}$. Therefore, the amount of AMC produced was proportional to the number of apoptotic cells in the treated sample Figure 5.

After visualizing caspase activity of $\mathbf{5 j}$ and $\mathbf{5 p}$ from enzyme kinetic assay Figure 5, we attempted to decipher apoptosis via caspase- 3 activation as a mechanism of their cytotoxicity using different biological assays Treatment of HL-60 cells with $5 \mathbf{j}$ and $\mathbf{5 p}$ at 5,10 and $15 \mu \mathrm{M}$ concentra-

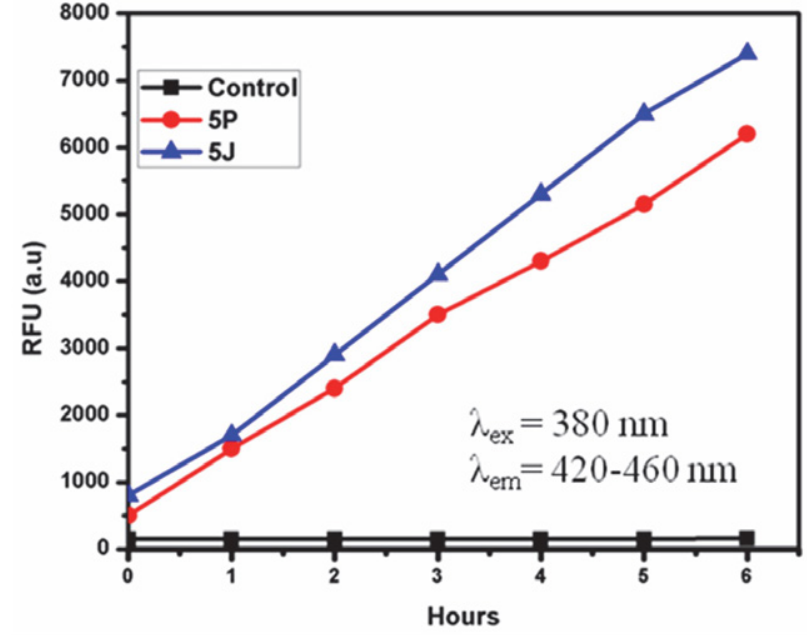

Figure 5: HL-60 cells were seeded in a 6-well plate at a density of 1 $\times 10^{5}$ cells/well, treated with $5 \mathbf{J}$ and $\mathbf{5 P}$ at various concentrations $(0-30 \mu \mathrm{M})$ for $48 \mathrm{hr}$ and then lysed with Lysis Buffer. Cell lysates were added to the assay plate carrying the substrate solution, at $37^{\circ} \mathrm{C}$ in dark. Relative fluorescent units (RFUs) were obtained at different time intervals.

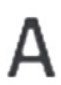

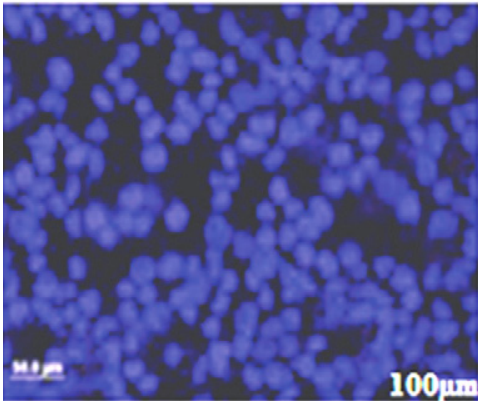

Negative Control

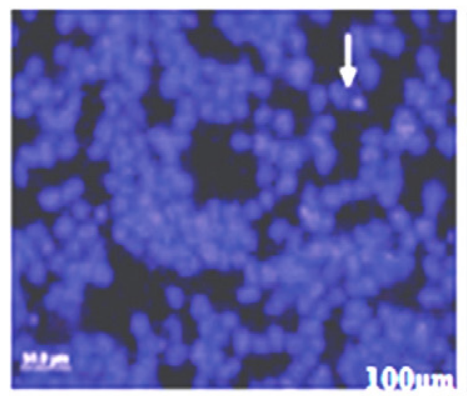

$5 \mathrm{j}(5 \mu \mathrm{M})$

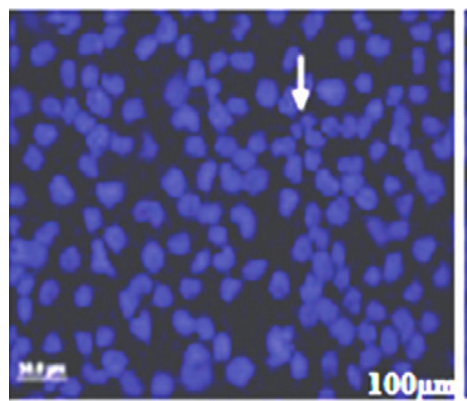

$5 \mathrm{p}(5 \mu \mathrm{I})$

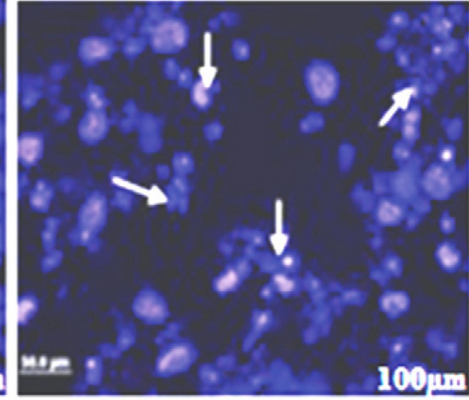

Camptothecinl $\mu . \mathrm{II}$

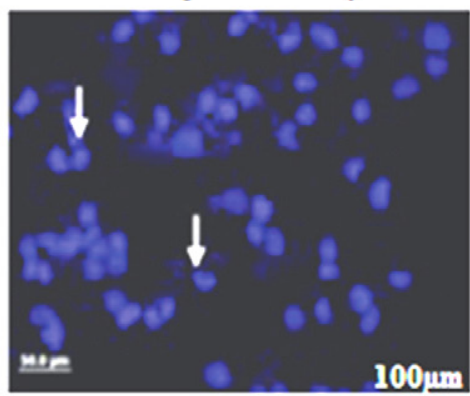

$5 \mathrm{j}(10 \mu \mathrm{II})$

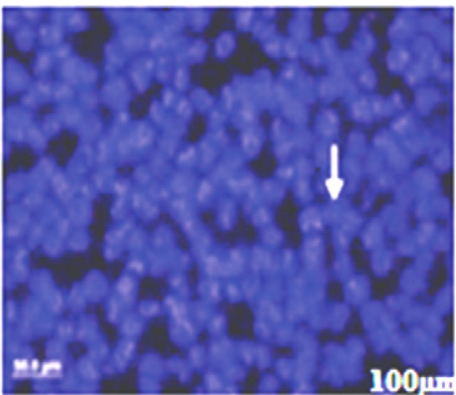

$5 p(10 \mu \backslash I)$

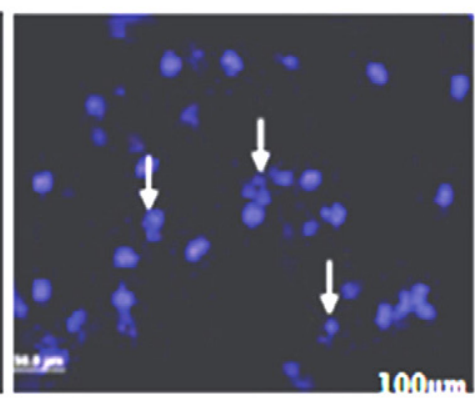

$5 \mathrm{j}(15 \mu \mathrm{I})$

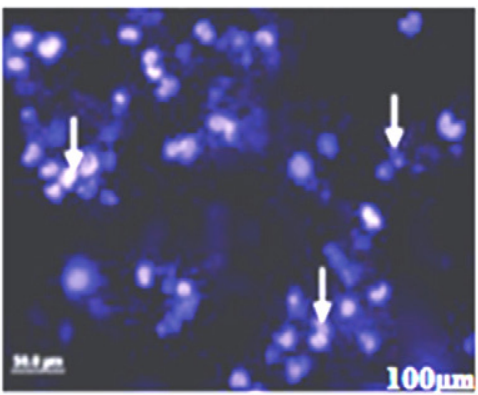

$5 \mathrm{p}(15 \mu \mathrm{M})$

Figure 6 A. $5 \mathbf{j}$ and $\mathbf{5 p}$ induce apoptosis in HL-60 cells. (A) Cells were treated with test compounds $5 \mathbf{j}$ and $\mathbf{5 p}$ at 5,10 and $15 \mu \mathrm{M}$ for $24 \mathrm{~h}$, stained with DAPI and observed under fluorescence micropscope. The arrow in each case showed appearance of apoptotic bodies. 

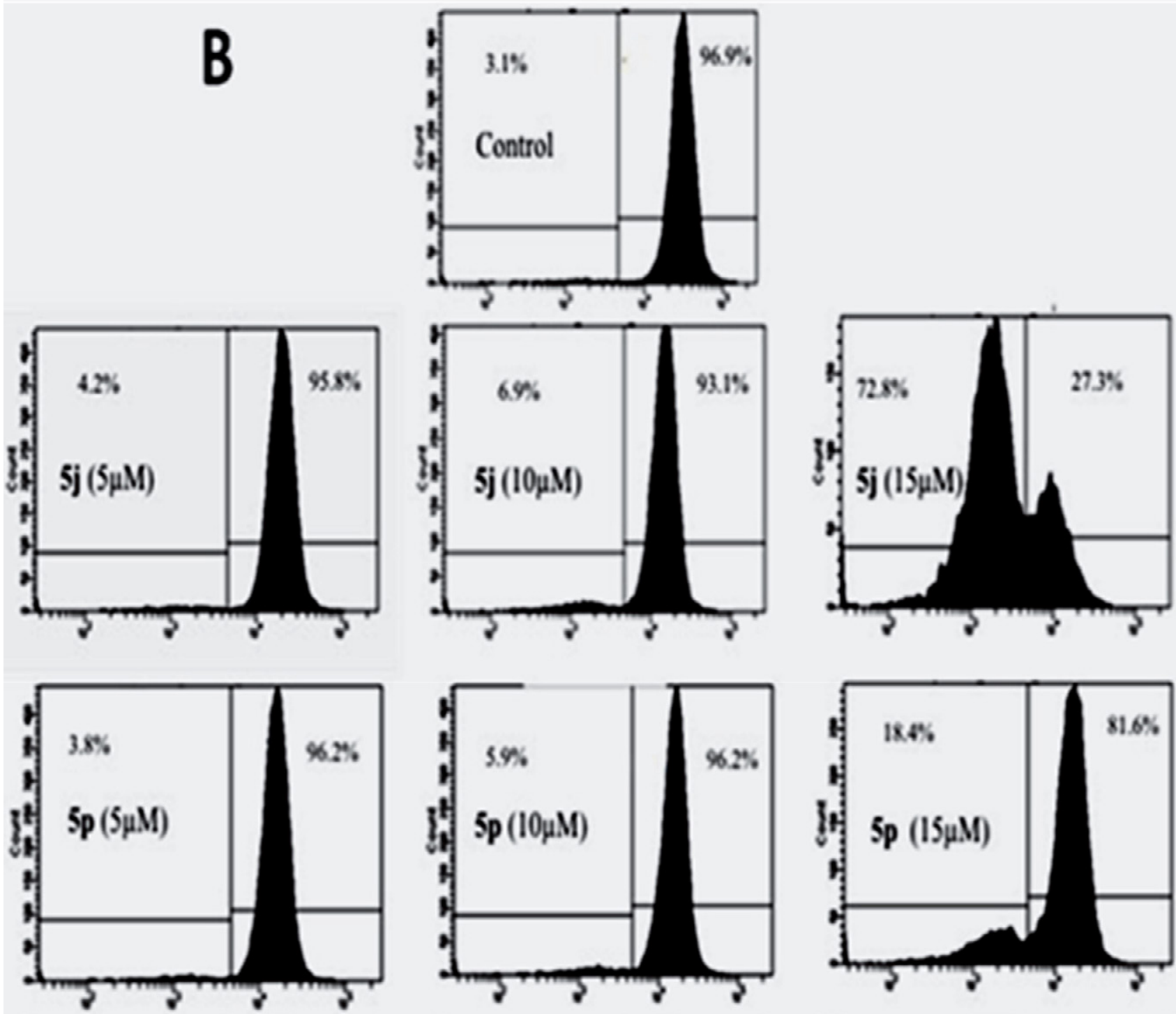

Figure 6B. (B) HL-60 cells were incubated with $(5,10$ and $15 \mu \mathrm{M})$ of compounds $5 \mathbf{j}$ and $\mathbf{5 p}$ for $24 \mathrm{~h}$ followed by staining with Rhodamine-123 (200 $\mathrm{nM}$ ) for $1 \mathrm{~h}$ and analyzed by flow cytometer. Data was analyzed by Cell Quest Pro software from BD Biosciences. Both the assays were repeated three independent times.

tions induced typical apoptotic response under microscopic analysis. Untreated cells were spherical in shape while as the treated cells showed membrane blebbing, shrinkage and condensation of nuclear material, reminiscent of the apoptosis induced by treatment with camptothecin, a known apoptotic inducer used as control drug. These results suggest that $\mathbf{5 j}$ and $\mathbf{5 p}$ induce apoptotic type cellular morphology in HL-60 cells in a dose dependent manner (Figure. 6A). These findings were further corroborated by loss in mitochondrial membrane potential in HL-60 cells induced by $5 \mathbf{j}$ and $\mathbf{5 p}$. The loss of mitochondrial trans-membrane potential $(\Delta \Psi \mathrm{m})$ is a precursory event that triggers mitochondrial matrix remodeling leading to cytochrome $c$ release. In turn the release of cytochrome $c$ from mitochondrial intermembrane space induces assembly of the apoptosome that is required for activating downstream caspases. ${ }^{36,37}$ To measure the mitochondrial membrane potential, the kinetics of Rhodamine-123 fluorescence quenching was evaluated using flow cytometry. The results indicated that at 5,10 and $15 \mu \mathrm{M}$ concentrations both $5 \mathbf{j}$ and $5 \mathbf{p}$ led to the dose dependent loss of mitochondrial membrane potential, with $5 \mathbf{j}$ showing a pronounced effect at $15 \mu \mathrm{M}$ concentration (Figure 6B).

In the cell cycle analysis studies, it was also observed that treatment of HL-60 cells with $\mathbf{5 j}$ and $\mathbf{5 p}$ exhibited a dose dependent increase in hypo diploid sub-G1 fraction, an indication of apoptotic population. In $\mathbf{5 j}$ treated cells, sub-G1 population increased with increasing concentration from $1.4 \%, 5 \%$ to $44.7 \%$ at 5,10 and $15 \mu \mathrm{M}$ respectively, whereas untreated control showed $1.4 \%$ sub-G1 DNA fraction. 5 p displayed a similar trend with $1.7 \%, 2.6 \%$ and 

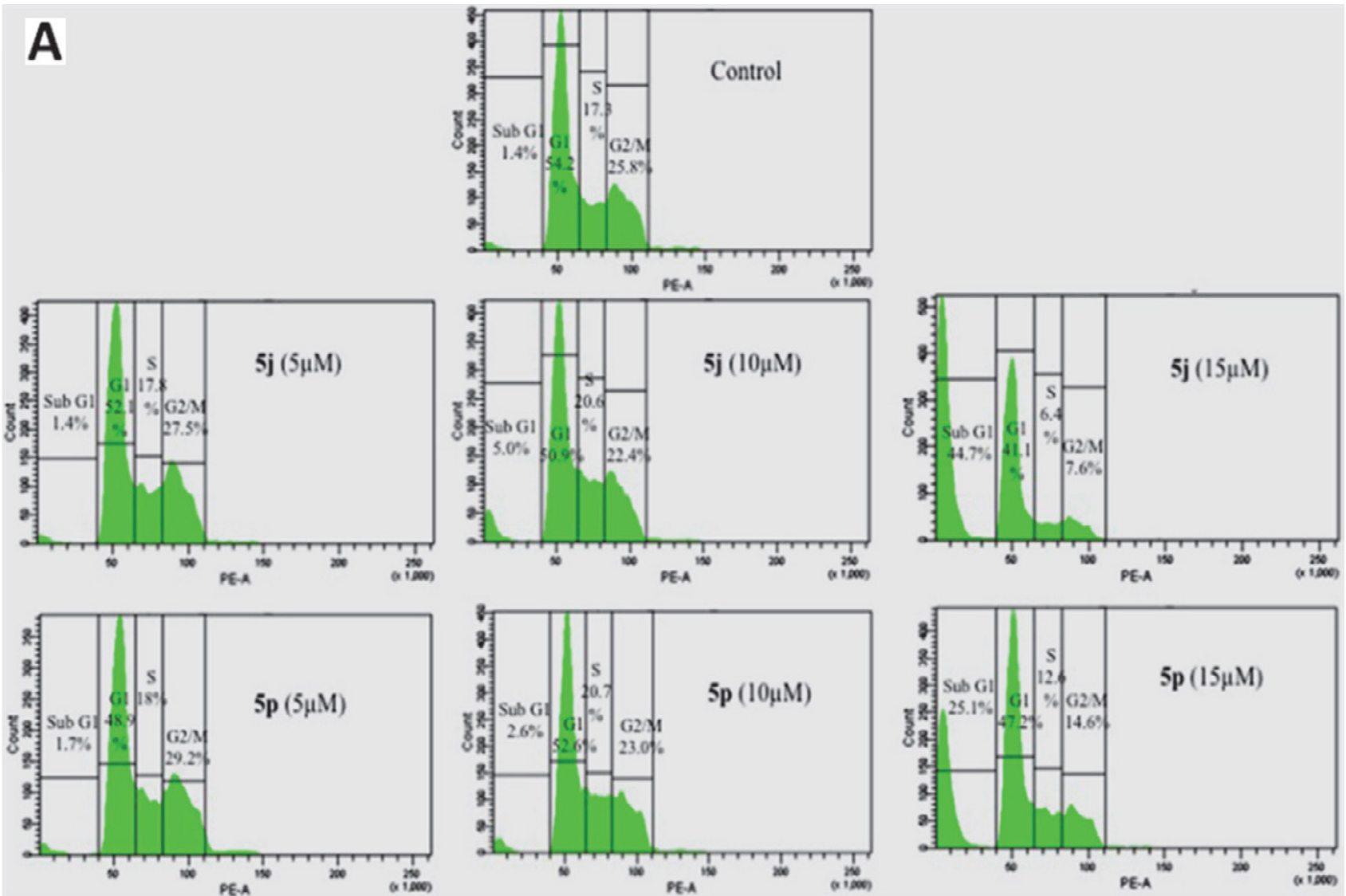

B
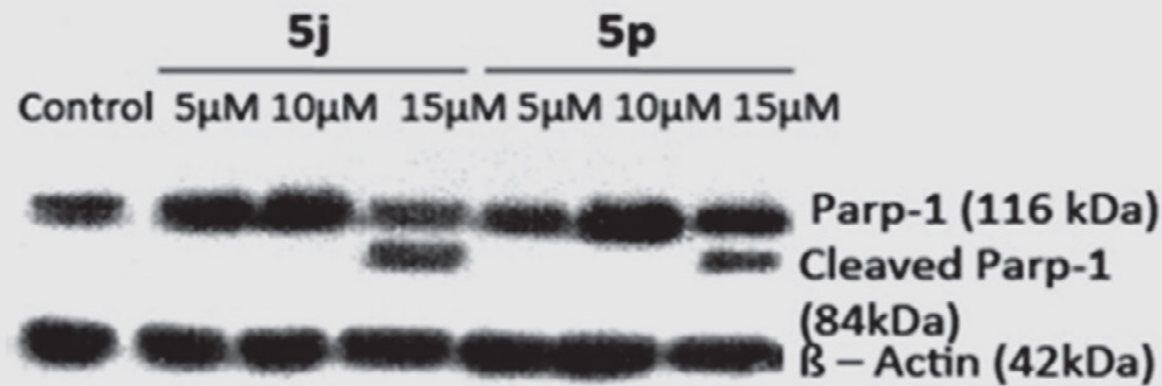

Figure 7.5j and $\mathbf{5 p}$ arrest cell cycle in sub-G1 phase and induce cleavage of PARP-1. Cells were treated with 5,10 and $15 \mu \mathrm{M}$ concentration of $\mathbf{5 j}$ and $5 \mathbf{P}$ and (A) cell cycle phase distribution analysis was carried by out Flow cytometry (B) representative blot indicating the cleavage status of PARP-1 in treated HL-60 cells.

$25.1 \%$ sub-G1 population at 5,10 and $15 \mu \mathrm{M}$ respectively (Figure 7A).

The confirmation of apoptosis by $\mathbf{5} \mathbf{j}$ and $\mathbf{5 p}$ was carried out through cleavage study of poly (ADP ribose) polymerase-1 (PARP-1) by using western blott. ${ }^{38}$ The western blot analysis of PARP-1 in HL-60 cancer cell line was performed following $24 \mathrm{~h}$ treatment with 5,10 and $15 \mu \mathrm{M}$ concentrations of $\mathbf{5 j}$ and $\mathbf{5 p}$. Densitometry of the protein was carried out and normalized with $\beta$-actin for analysis. From results it was observed that both $\mathbf{5 j}$ and $\mathbf{5 p}$ induce cleavage of PARP-1, thus contributing towards activation of apoptotic pathways (Figure 7B)

\section{4. Lead Molecules of Benzyl-pyrrolidine-3- ol Analogues Stably Interact with Bovine Serum Albumin}

Serum albumins are abundant plasma proteins for transportation and stabilization of drug molecules within biological system. ${ }^{39}$ Bovine Serum Albumin (BSA) is a close similitude of Human Serum Albumin (HSA) and has been extensively studied as model carrier protein. From the pharmaceutical perspectives of bioavailability, and drug stability under physiological conditions, we investigated interaction of $5 \mathbf{j}$ and $\mathbf{5 p}$ with BSA through molecular 

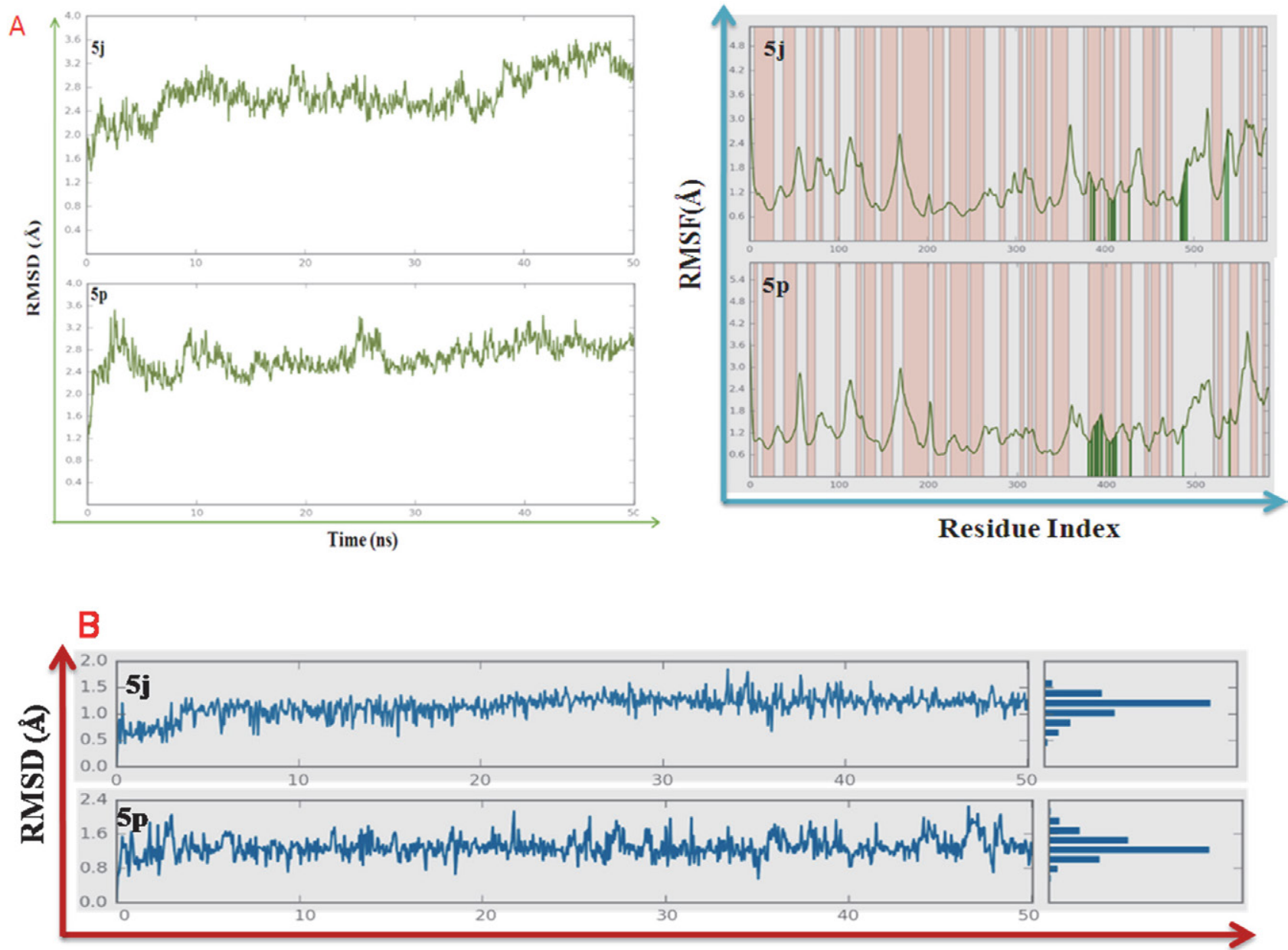

Time (ns)

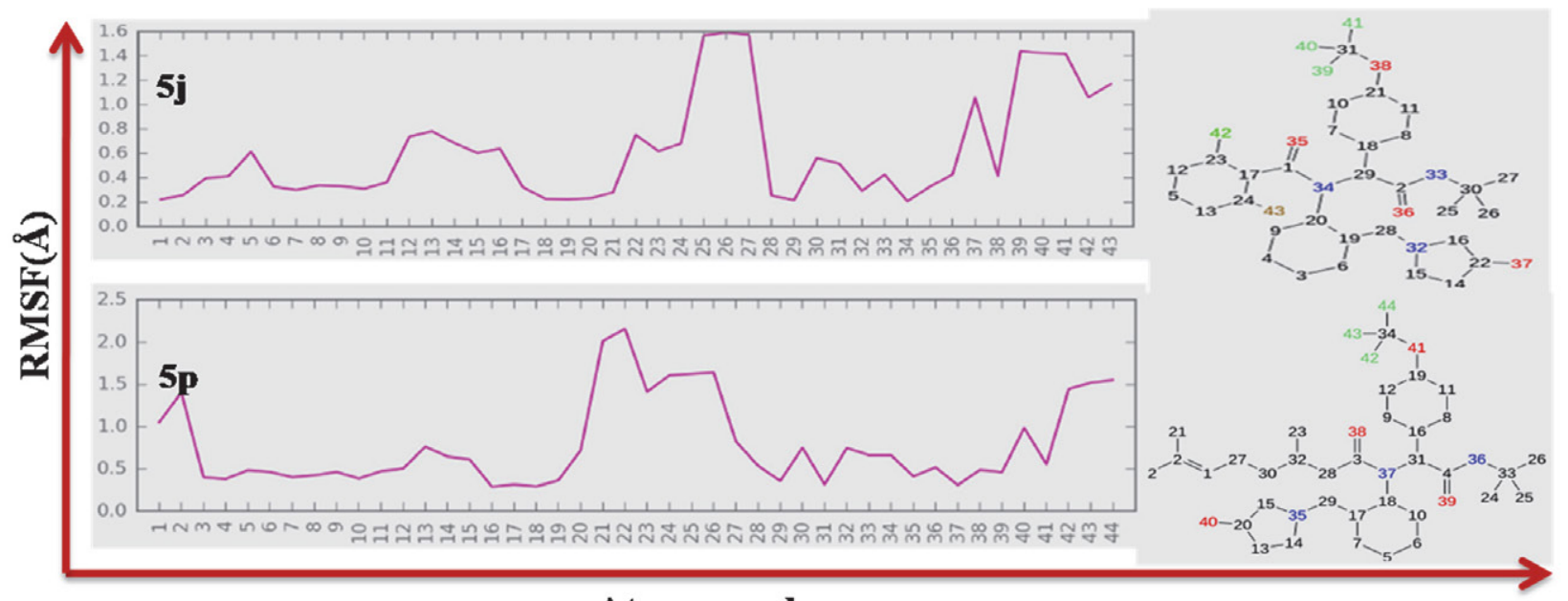

Atom numbers

Figure 8: Graphical representation of the (A) Protein (B) Ligand-RMSD and RMSF plots with respect to time and atom number respectively between $5 \mathbf{j}$ and $5 \mathbf{p}$ and BSA during the 50 ns simulation.

dynamic simulations and further substantiated with various biophysical methods. ${ }^{40}$ For an insight in the interaction of $\mathbf{5 j}$ and $\mathbf{5 p}$ with BSA carrier protein, MD simulations were performed on their best docked pose. The essential descriptors: RMSD, RMSF and number of contacts formed throughout the simulation were calculated for both $\mathbf{5 j}$ and $\mathbf{5 p}$ with BSA. The ligand-RMSD and ligand-RMSF were determined to assign the stability of $\mathbf{5 j}$ 
and $\mathbf{5 p}$ within the binding pocket of BSA (Figure $8 \mathrm{~A}$ ). It is evident from the ligand RMSD plots that the compound $\mathbf{5 j}$ and $5 \mathbf{p}$ have shown an average deviation within the window size of $0.5-1.3 \AA$ and $0.8-1.5 \AA$ respectively. These small deviations endorse stability of ligands within the binding pocket. In addition, the ligand-RMSF plots were exploited to depict the atomic fluctuation of the ligand atoms. It was noticed that the polar group atoms of the lead molecules displayed elevated fluctuations as compared to the atoms buried deep within the binding pocket. The protein RMSD plots of $\mathbf{5 j}$ and $\mathbf{5 p}$ BSA complexes show fluctuations upto $3.6 \AA$ during the simulations (Figure $8 \mathrm{~B}$ ). These results indicate that binding of the $5 \mathbf{j}$ and $5 \mathrm{p}$ have induced minor conformational changes in the protein backbone. Owing to the inherent flexibility of loops and terminals, the undulation in protein-RMSF upto $3.5 \AA$ was noticed for the residues $250-300$ and above 500 for $5 \mathbf{j}$ whereas, upto $4.0 \AA$ for the residues 500 and above for $5 \mathrm{p}$. The protein-RMSF for most of the residues of $\mathbf{5 j}$-BSA and $\mathbf{5 p}$-BSA complexes stays below $1.8 \AA$ and $1.5 \AA$ respectively. These fewer fluctuations can be attributed to the secondary structure elements viz. alpha helices and beta strands and were observed throughout the $50 \mathrm{~ns}$ simulation run.

The formation of protein-ligand contact plays an important role in the complex binding, the different kinds of contacts established during the $50 \mathrm{~ns}$ simulation run were investigated and are highlighted in protein-ligand interaction diagram (Figure 8B) Compared to $5 \mathbf{j}$, more number of contacts were noticed for $\mathbf{5 p}$, which can be attributed to its extended chemical structure. Taken together, the essential parameters observed for both $\mathbf{5 j}$ and $\mathbf{5 p}$ BSA complexes are well within the acceptable limit which indicates their stability inside the binding pocket of BSA. Thus, $\mathbf{5 j}$ and $\mathbf{5 p}$ can be considered as effective BSA binders and therefore can be predicted to have good stability and mobility towards their biotargets under physiological conditions.

The in silico predictions of $\mathbf{5 j}$ and $\mathbf{5 p}$ as BSA binding compounds were verified by absorption and fluorescence quenching experiments. The absorption spectrum of pure BSA shows a peak at $280 \mathrm{~nm}$ which undergoes a hypochro-
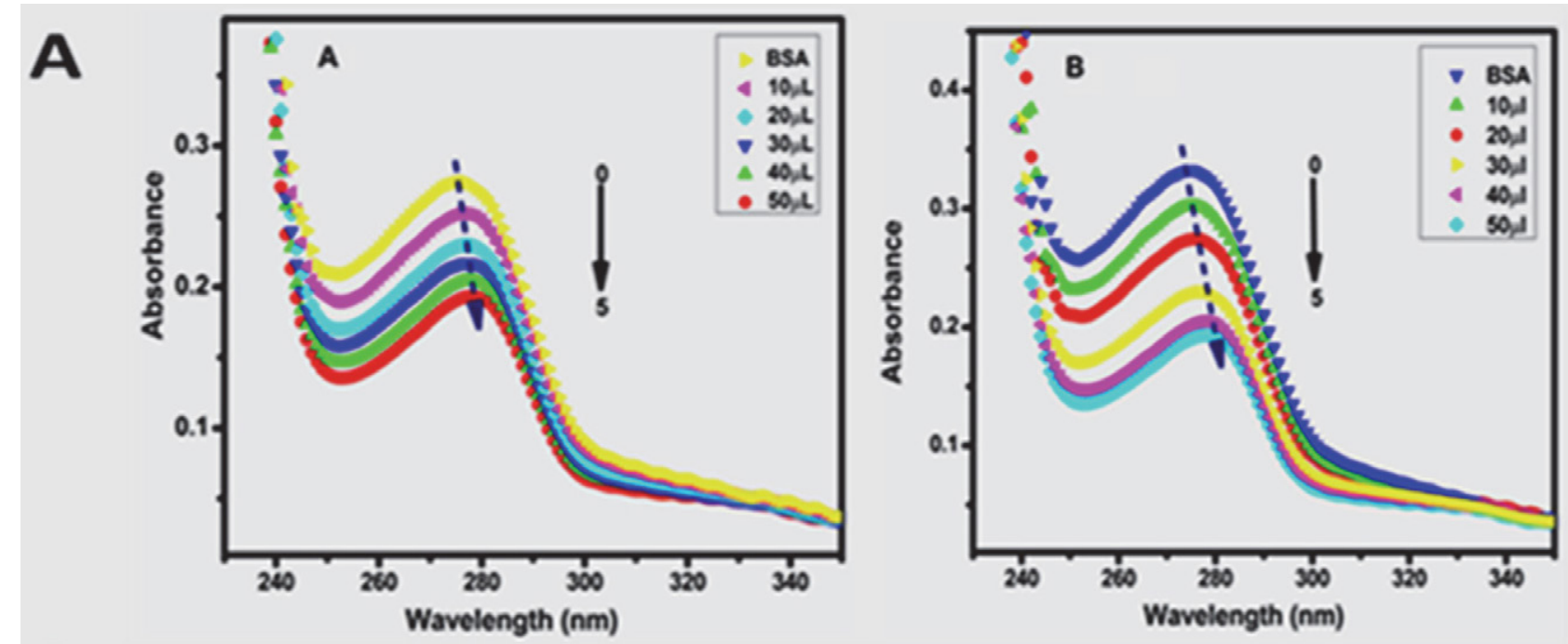

B
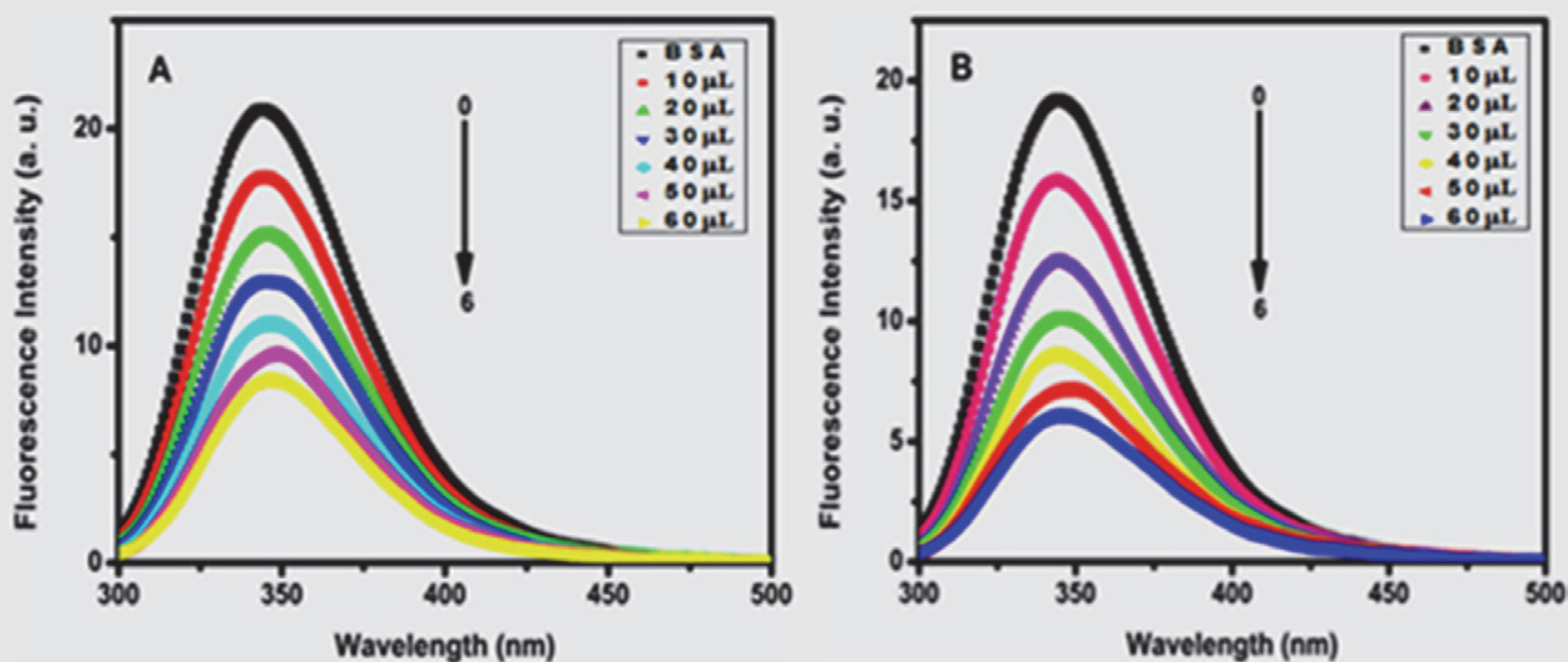

Figure 9: Changes in (A) absorption spectra and (B) emission spectra of BSA on addition of $10-50 \mu \mathrm{L}$ of $1 \mathrm{mM}$ of $\mathbf{5 j}$ and $\mathbf{5 p}$. 
mic effect with a slight bathochromic shift on sequential addition of $\mathbf{5 j}$ and $\mathbf{5 p}$ respectively (Figure $9 \mathrm{~A}$ ). These results suggest that both $\mathbf{5 j}$ and $\mathbf{5 p}$ interact with BSA and also possibly induce some structural changes in modular carrier protein. BSA shows a strong emission peak at $\lambda \mathrm{em}$ $350 \mathrm{~nm}$ when excited at $\lambda$ ex $280 \mathrm{~nm}$, attributed to the Trp residue. Changes in the emission maximum of BSA in presence of added drug are a mark of protein drug interaction. The effect of increasing concentrations of $5 \mathbf{j}$ and $\mathbf{5 p}$ on the fluorescence emission spectra of BSA is shown in (Figure 9B) The BSA emission undergoes a dose dependant hypochromic effect (intrinsic fluorescence quenching) upon sequential addition of $5 \mathbf{j}$ and $5 \mathrm{p}$ indicating that both $5 \mathbf{j}$ and $\mathbf{5 p}$ interact with BSA with relatively more, quenching in case of $\mathbf{5 p}$ compared to $\mathbf{5 j}$.

Stern-Volmer analysis was used to analyze the fluorescence quenching data of BSA with $\mathbf{5 j}$ and $\mathbf{5 p}$ equations $1-2$.

$$
\begin{aligned}
& \mathrm{F}^{0} / \mathrm{F}=1+\mathrm{KSV}[\mathrm{Q}]=1+\mathrm{Kq}^{0}[\mathrm{Q}] \\
& \& \mathrm{Kq}=\mathrm{KSV} / \tau^{0}
\end{aligned}
$$

where $\mathrm{F}^{0}$ and $\mathrm{F}$ are the fluorescence intensities of BSA in the absence and presence of quencher; [Q] represents quencher concentration, KSV is the Stern-Volmer quenching constant, $\mathrm{Kq}$ is the quenching rateconstant and $\tau^{0}$ is the average lifetime of molecule in the absence of drug and its value is $10^{-8} \mathrm{sec}^{24}$ The calculated Stern-volmer constants (KSV) for $5 \mathbf{j}$ and $5 \mathbf{p}$ are $5.1 \times 10^{4} \mathrm{M}^{-1}$ and $6.71 \times 10^{4} \mathrm{M}^{-1}$ respectively indicating that quenching of BSA by $5 \mathbf{p}$ is more compared to $\mathbf{5 j}$. Figure 10 depicts Stern-Volmer plots of $5 \mathbf{j}$ and $\mathbf{5 p}$ at three different temperatures with the corresponding KSV values shown in Table S4. On increasing the temperature from $298 \mathrm{~K}$ to $308 \mathrm{~K}$, KSV values de- crease from $5.1 \times 10^{4} \mathrm{M}^{-1}$ to $2.14 \times 10^{4} \mathrm{M}^{-1}$ in case of $5 \mathbf{j}$ and $6.71 \times 10^{4} \mathrm{M}^{-1}$ to $3.91 \times 10^{4} \mathrm{M}^{-1}$ in case of $5 \mathrm{p}$. The calculated value of $\mathrm{Kq}$ for both $\mathbf{5 j}$ and $\mathbf{5 p}$ was found to be greater than the maximum scatter collision quenching constant, i.e. $2 \times 10^{10} \mathrm{~L} \mathrm{~mol}^{-1} \mathrm{~s}^{-1}$. Thus, observed changes in absorption spectra, temperature trend of KSV value and calculated quenching rate constants more than maximum scatter collision quenching suggest static quenching as plausible mechanism of BSA by $\mathbf{5 j}$ and $\mathbf{5 p} .{ }^{41}$

\section{Conclusion}

Synthesis and investigation of apoptotic propensity of structurally diverse benzylpyrrolidin-3-ol analogues using in-silico and in-vitro methods is presented. The compounds $5 \mathbf{j}$ and $\mathbf{5 p}$ were identified as lead cytotoxic molecules from Ugi four component reaction synthesized library of sixteen compounds (5a-p). The lead compounds $5 \mathbf{j}$ and $\mathbf{5 p}$ exhibited proportionally higher cytotoxicity towards HL-60, as compared to cell lines derived from solid tumors. Besides, their milder cytotoxic effects on non-cancerous cell lines indicate selective action towards cancer cells. The docking and molecular dynamic simulation (MDS) of the lead molecules with caspase-3 as a major mediator of apoptosis predicted apoptosis as potential cytotoxicity mechanism. Various covalent and non-covalent interactions were shown to be involved between compounds (5a-p) and amino acids present around active site of caspase- 3 . The MDS results of $5 \mathbf{j}$ and $\mathbf{5 p}$ complexes with caspase- 3 indicate that their binding to caspase- 3 is very stable and does not affect the overall architecture of protein. However their binding brings some aberrant action which propels apoptosis. The in silico prediction was confirmed by in vitro apoptotic markers: loss of mitochondrial
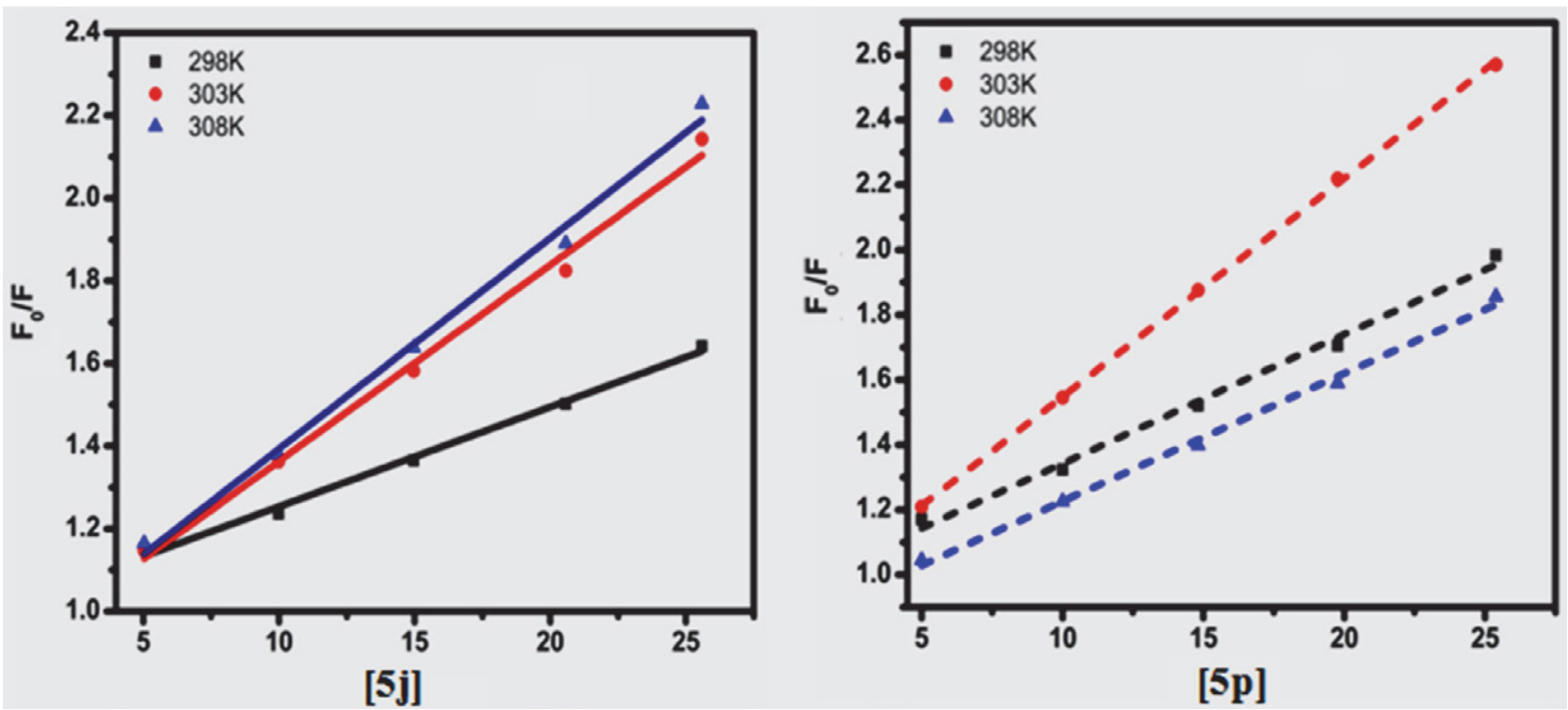

Figure 10: Stern-Volmer plots for binding of $\mathbf{5 j}$ and $\mathbf{5} \mathbf{p}$ with BSA at three temperatures. 
membrane potential, cell cycle analysis emergence of apoptotic bodies under fluorescence microscopy. Besides, cleavage of PARP- 1 confirmed that both $\mathbf{5 j}$ and $\mathbf{5 p}$ induce apoptotic cell death in a dose dependant manner. From the perspective of drug bioavailability, and stability, interaction of lead molecules $(\mathbf{5 j}$ and $\mathbf{5 p}$ ) with Bovine Serum Albumin (BSA) as model protein was investigated using in silico molecular dynamics (MD) simulations and also substantiated by biophysical methods. Both $\mathbf{5 j}$ and $\mathbf{5 p}$ were observed to bind to BSA with a good binding constant and hence can be considered to be stable and available to their biotargets under physiological conditions.

\section{Supporting Information Summary}

Supporting information includes methods and materials used for biological activity studies. Detailed insilico procedure. The tables TS1 to TS3 in supporting file depict cytotoxic selectivity, IC50 and BSA binding data. Apart for experimental details, characterization data $\left({ }^{1} \mathrm{HNMR}\right.$, ${ }^{13}$ CNMR and Mass spectra) of the benzylpyrrolidin-3-ol analogues compounds (5a-5p),

\section{References}

1. D. R Green, S. J Martin, Curr Opin Immunol. 1995, 7, 694703. DOI:10.1016/0952-7915(95)80079-4

2. D. Hanahan, R. A. Weinberg, Cell. 2011, 144, 646-674. DOI:10.1016/j.cell.2011.02.013

3. M. O. Hengartner, Nature 2000, 407, 770-776. DOI:10.1038/35037710

4. A. Domling, I. Ugi, Angew. Chem. Int. Ed. Engl. 2000, 39, 3168-3210.

DOI:10.1002/1521-3773(20000915)39:18<3168::AID-ANIE 3168>3.0.CO;2-U

5. A. Domling, Chem. Rev. 2006, 106, 17-89.

DOI:10.1021/cr0505728

6. K. Tamazawa, H. Arima, T. Kojima, Y. Isomura, M. Okada, S. Fujita, T. Furuya, T. Takenaka, O. Inagaki, M. M Terai, J. Med. Chem. 1986, 29, 2504-2511. DOI:10.1021/jm00162a013

7. C. Palombo, E. Malshi, C. Morizzo, F. Rakebrandt, V. Corretti, F. Santini, A. G. Fraser, M. Kozakova, Clin. Ther. 2009, 31, 2873-2885. DOI:10.1016/j.clinthera.2009.12.011

8. E. Rubinstein, Chemotherapy 2001, 47, 3-8.

DOI:10.1159/000057837

9. T. Miyadera, Y. Sugimura, T. Hashimoto, T. Tanaka, K. Iino, T. Shibata, S. Sugawara, J. Antibiot. 1983, 36, 1034-1039.

DOI:10.7164/antibiotics.36.1034

10. T. Nagahara, Y. Yokoyama, K. Inamura, S. Katakura, S. Komoriya, H. Yamaguchi, T. Hara, M. Iwamoto, J. Med. Chem. 1994, 37, 1200-1207. DOI:10.1021/jm00034a018

11. H. Yonehara, H. Seto, S. Aizawa, T. Hidaka, A. Shimazu, N. Otake, J. Antibiot. 1968, 21, 369-370.

DOI:10.7164/antibiotics.21.369

12. R. M. Jagtap, M. A. Rizvi, Y. B. Dangat, S. K. Pardeshi, J. SulfurChem. 2016, 37, 401-425.
DOI:10.1080/17415993.2016.1156116

13. N. Chalotra, A. Ahmed, M. A. Rizvi, Z. Hussain, Q. N. Ahmed, B. A. Shah, J. Org. Chem. 2018, 83, 14443-14456. DOI:10.1021/acs.joc.8b02193

14. S. Sultan, M. S. Bhat, M. A. Rizvi, B. A. Shah, J. Org. Chem. 2019, 84, 8948-8958. DOI:10.1021/acs.joc.9b00855

15. N. Chalotra, M. A. Rizvi, B. A. Shah, Org. Lett, 2019, 21, 4793-4797. DOI:10.1021/acs.orglett.9b01677

16. J. Kumar, A. Ahmad, M. A. Rizvi, M. A. Ganie, C. Khajuria, B. A. Shah, Org. Lett. 2020, 22, 4793-4797. DOI:10.1021/acs.orglett.0c02055

17. M. A. Rizvi, S. K. Moosvi, T. Jan, S. Bashir, P. Kumar, W. D. Roos, H. C. Swart, Polymer. 2019, 163, 1-12

DOI:10.1016/j.polymer.2018.12.044

18. G. Ali, N. A. Dangroo, S. Raheem, T. Naqvi, T. Ara M. A. Rizvi, Acta Chim. Slov. 2020, 67, 195-202.

DOI:10.17344/acsi.2019.5348

19. F. Kouser, V. K. Sharma, M. Rizvi, S. Sultan, N. Chalotra, V. K. Gupta, U. Nandi, B. A. Shah, TetrahedronLett. 2018, 59, 2161-2166 DOI:10.1016/j.tetlet.2018.04.046

20. M. Kumar, A. Kumar, M. A. Rizvi, B. A. Shah, RSC Adv. 2015, 5, 55926-55937. DOI:10.1039/C5RA05695K

21. M. A. Rizvi, N. Teshima, G. M. Peerzada Croat. Chem. Acta, 2013, 86, 345-350. DOI:10.5562/cca2167

22. A. Kumar, M. A. Rizvi, S. Kumar, S. Bhushan, F. A. Malik, N. Batra, A. Joshi, J. Singh, Chem. Biol. Interact . 2014, 222, 60-67. DOI:10.1016/j.cbi.2014.08.011

23. A. Pandey, M. A. Rizvi, B. A, Shah, S. Bani, Cytokine 2016, 79, 103-113. DOI:10.1016/j.cyto.2016.01.004

24. M. Kumar, A. Kumar, M. Rizvi, M. Mane, K. Vanka, S. C. Taneja, B. A. Shah, Eur. J. Org. Chem. 2014, 2014, 5247-5255. DOI:10.1002/ejoc.201402551

25. M. A. Rizvi, M. Mane, M. A. Khuroo, G. M. Peerzada, Monatsh Chem, 2017, 148, 655-668.

DOI:10.1007/s00706-016-1813-8

26. Y. Dangat, M. A. Rizvi, P. Pandey, K. Vanka, J. Organomet. Chem., 2015, 801, 30-41.

DOI:10.1016/j.jorganchem.2015.10.015

27. M. V. Mane, M. A. Rizvi, K. Vanka, J. Org. Chem. 2015, 80, 2081-2091. DOI:10.1021/jo5023052

28. A. Kumawat, S. Raheem, F. Ali, T. A. Dar, S. Chakrabarty, M. A. Rizvi, J. Phys. Chem. B 2021, 125, 6, 1531-1541. DOI:10.1021/acs.jpcb.0c08111

29. M. Zhou, X. Liu, Z. Li, Q. Huang, F. Li, C. Y. Li, Int. J. Cancer. 2018, 143, 921-930. DOI:10.1002/ijc.31374

30. X. Feng, Y. Yu, S. He, J. Cheng, Y. Gong, Z Zhang, X. Yang, B. Xu, X. Liu, CY. Li, L. Tian, Q. Huang, Cancer Lett. 2017, 385, 12-20. DOI:10.1016/j.canlet.2016.10.042

31. M. Mukai, T. Kusama, Y. Hamanaka, T. Koga, H. Endo, M. Tatsuta, M. Inoue, CancerRes. 2005, 65, 9121-9125. DOI:10.1158/0008-5472.CAN-04-4344

32. K. Lauber, E. Bohn, S. M. Krober, Y. J. Xiao, S. G. Blumenthal, R. K. Lindemann, P. Marini, C. Wiedig, A. Zobywalski, S. Baksh, Y. Xu, I. B. Autenrieth, K. S. Osthoff, C. Belka, G. Stuhler, S. Wesselborg, Cell. 2003, 113, 717-730.

DOI:10.1016/S0092-8674(03)00422-7

33. L. Flanagan, M. Meyer, J. Fay, S. Curry, O. Bacon, H. Duess- 
mann, K. John, KC. Boland, DA. McNamara, E. W. Kay, H. Bantel, H. Schulze Bergkamen, J. H. M. Prehn., Cell Death Dis. 2016, 7: e2087. DOI:10.1038/cddis.2016.7

34. Q. P. Peterson, D. R. Goode, D. C. West, K. N. Ramsey, J. J. Lee, P. J. Hergenrother, J. Mol. Biol., 2009, 388, 144-158. DOI:10.1016/j.jmb.2009.03.003

35. Q. P. Peterson, D. C. Hsu, D. R. Goode, C. J. Novotny, R. K. Totten, P. J. Hergenrother, J. Med. Chem. 2009, 52, 5721-5731. DOI:10.1021/jm900722z

36. M. O. Hengartner, Nature, 2000. 407, 770-776. DOI: $10.1038 / 35037710$

37. C. Adrain, S. J. Martin, Trends Biochem. Sci., 2001, 26, 390397. DOI:10.1016/S0968-0004(01)01844-8
38. C. Soldani, A. I. Scovassi, Apoptosis, 2002 7, 321-328. DOI:10.1023/A:1016119328968

39. F. Mirzaee, L. Hosseinzadeh, M. R. Ashrafi-Kooshk, S Esmaeili, S Ghobadi, M. H. Farzaei, M. R Zad-Bari, R Khodarahmi, Protein Pept. lett. 2019, 26, 132-47. DOI:10.2174/0929866525666181114152242

40. M. A. Rizvi, Z. Hussain, F. Ali, A. Amin, S. H. Mir, G. Rydzek, R. M. Jagtap, S. K. Pardeshi, R. A. Qadri K. Ariga, Phys. Chem. Chem. Phys., 2020, 22, 7942-7951 DOI:10.1039/D0CP00253D

41. M. A. Rizvi, M. Zaki, M. Afzal, M. Mane, M. Kumar, B. A. Shah, S. Srivastav, S. Srikrishna, G. M. Peerzada, S. Tabassum, Eur. J. Med. Chem. 2015, 90, 876-888.

DOI:10.1016/j.ejmech.2014.12.014

\section{Povzetek}

Aktivacija kaspaz je osrednjega pomena za apoptozni proces v živih sistemih. Napake v apoptozi so povezane s karcinogenezo. Potreba po razvoju pametnih učinkovin, ki bi lahko povzročila apoptozo v tumorskih celicah, je očitna. S tem namenom je bila predvidena sinteza raznolikih analogov 1-benzilpirolidin-3-ola. Pripravljena je bila večkomponentna, $\mathrm{z}$ Ugi reakcijami sintetizirana knjižnica analogov in raziskana njihova citotoksičnost na naboru človeških rakavih celičnih linij pri koncentraciji $10 \mu \mathrm{M}$. Spojini vodnici kažeta selektivno citotoksičnost za celice HL-60 v primerjavi s celičnimi linijami, pridobljenimi iz trdnih tumorjev. Poleg tega njihov blažji citotoksični učinek na nerakave celične linije dodatno potrjuje njihovo selektivnost za rakave celice. Spojini vodnici sta bili testirani za njihovo sposobnost ciljanja kaspaze-3 kot glavne proteaze, ki sproži apoptozo. Opaženo je bilo, da spojini vodnici inducirata apoptozo v celicah HL-60 pri koncentraciji $10 \mu \mathrm{M}$. Spojini vodnici sta izkazovali različne nekovalentne interakcije supra tipa s ključnimi preostanki kaspaze-3 v okolici aktivnega mesta. Sposobnost vezave spojin vodnic s kaspazo-3 so preučevali z molekularnim sidranjem in simulacijami molekularne dinamike (MD). Simulacije MD so pokazale stabilnost kompleksa s kaspazo-3 v celotnem simulacijskem ciklu 50 ns. Stabilnost in biološko uporabnost spojin vodnic v fizioloških pogojih je bila ocenjena $\mathrm{z}$ njihovo interakcijo z govejim serumskim albuminom (BSA) kot modelnim proteinom. Interakcije BSA s spojinami vodnicami so bile preučene $\mathrm{z}$ različnimi biofizikalnimi metodami in nadalje potrjene $\mathrm{z}$ računalniškimi simulacijami MD. 